Diterbitkan oleh Fakultas Sastra dan Budaya

Universitas Ahmad Dahlan Yogyakarta

\title{
Identitas dalam Iklan Pemilu SBY dan Megawati
}

\author{
Oleh: Anang Masduki \\ Dosen Ilmu Komunikasi Universitas Ahmad Dahlan Yogyakarta \\ Email: anang_masduki@yahoo.com
}

\begin{abstract}
Abstrak
Politisi memerlukan sebuah identitas yang disematkan pada dirinya untuk menaikan elektabilitas dalam pemilu. Dan salah satu instrumen untuk mengkomunikasikan identitas tersebut adalah iklan politik. Dalam penelitian ini akan diulas mengenai politik identitas yang dilakukan oleh pasangan Mega-Prabowo dan SBY-Budiono dalam iklan kampanye pemilu tahun 2009. Hasilnya terdapat empat politik identitas yang ditonjolkan, yaitu kenegarawanan, kerakyatan, kemakmuran dan multikultural. Identitas politik kemiskinan dan kerakyatan dilakukan oleh kedua kandidat, adapun identitas kenegarawanan dilakukan oleh pasangan Mega-Prabowo dan identitas multikulturalis dilakukan oleh pasangan SBY-Budiono.
\end{abstract}

Kata Kunci: Politik identitas, iklan politik, komunikasi politik.

\section{A. Latar Belakang}

Tumbangnya rezim otoritarian Orde Baru mengawali lahirnya masyarakat Indonesia baru, dimana kebanyakan orang menamainya sebagai orde reformasi. Banyak yang memiliki ekspektasi dalam orde reformasi, di antaranya tumbuh masyarakat yang demokratis. Kalau merujuk UUD 1945 masyarakat demokratis adalah segala sesuatu dari rakyat, oleh rakyat dan untuk rakyat dalam artian yang sesungguhnya. Harapan masyarakat itu sedikit demi sedikit mulai menampakan wujudnya. Hal ini ditandai dengan penatan ulang sistem pemerintahan dengan mengamandemen UUD 1945. Implikasinya Presiden dan kepala daerah dipilih dengan langsung oleh rakyat, kebebasan pers terjamin, TNI lepas dari peran politik, menjamurnya partai politik dan masih banyak lagi.

Perkembangan jumlah partai politik yang begitu pesat ditambah dengan mekanisme pemilihan kepala daerah langsung, termasuk pemilihan presiden, memiliki konsekuensi persaingan dalam merebutkan suara begitu masif dan ketat. Hal ini membuat para pengurus partai berpikir keras dan berusaha dengan sekuat tenaga untuk memperoleh suara sebanyak-banyaknya. Bahkan terkadang dengan menghalalkan segala cara. Sebut saja kasus korupsi yang menjerat beberapa elit partai, bendahara partai Demokrat M. Nazarudin, Presiden partai keadilan sejahtera. Terungkap dalam persidangan bahwa selain dana itu digunakan untuk memperkaya sendiri, tetapi juga digunakan untuk mengerakan mesin partai guna mendulang suara.

Untuk mencapai suara yang maksimal tentunya strategi komunikasi politik menjadi agenda utama. Partai atau calon kepala daerah bahkan calon presiden dikemas begitu rupa agar citra yang terbagun pada masyarakat atau pemilik suara menjadi positif, cerdas, 
visioner, memiliki keberpihakan pada masyarakat kecil dan baik hati. Misalnya, ketika beriklan pakaian yang digunakan menyerupai Soekarno, merangkul para pedagang atau petani, menggendong anak kecil, makan nasi aking. Maka menjamurlah lembaga konsultan politik. Hal ini terkadang mengaburkan subtansi dari nilai-nilai moral, budaya bahkan nilainilai demokrasi itu sendiri. Kaburnya nilai-nilai tersebut dapat dilihat dari kontrasnya perilaku kehidupan mereka sehari-hari dengan apa yang ditampilkan dalam iklan. Kebanyakan mereka hidup bergelimang harta, hidup enak, mereka rata-rata pernah menjadi pejabat. Sebut saja Prabowo yang mempunyai kekayaan 1 trilyun lebih dan mempunyai masalah dengan HAM ketika awal revormasi. Sedangkan dalam iklan, mereka jarang menonjolkan kemewahan yang dia miliki. Maka imbasnya, tak jarang kemudian masyarakat menjadi apatis terhadap pesta demokrasi itu sendiri, dimana dari masa awal reformasi sampai sekarang jumlah pemilih yang mendatangi tempat pemungutan suara (TPS) semakin merosot. Menurut ketua KPU, Husni Kamil Manik jumlah pemilih pada pemilu 1999, tingkat partisipasi 93 persen, pemilu 2004 tingkat partisipasi 84 persen, atau menurun 9 persen. Sedangkan pemilu 2009, turun lagi menjadi 71 persen, atau berkurang 13 persen. Tren penurunan 4 persen, (viva.co.id: 2014).

Oleh karena itu perlu diungkap politik identitas apasaja yang dimunculkan untuk menaikan elektabilitas. Dalam penelitian ini akan diulas mengenai politik identitas yang dimunculkan oleh pasangan SBY-Budiono dan pasangan Mega-Prabowo. Iklan yang diteliti adalah iklan pemilu di TV pada pemilu tahun 2009.

\section{B. Kajian Teoritik}

Brian McNair mendefinisikan iklan politik sebagai,

"Sebuah media yang untuk mengirimkan pesan-pesan politik kepada khalayak. Media yang digunakan untuk tujuan ini mencakup bioskop, billboard, pers, radio, televisi dan internet" (McNair : 2011, 87-88).

Definisi yang diberikan oleh McNair tersebut lebih dekat dengan teori komunikasi massa. Sehingga iklan politik dianggap sebagai sebuah media untuk mengirimkan pesan kepada khalayak.

Dalam buku Handbook Political Communication, Lynda Lee Kaid mendefinisikan iklan politik sebagai,

"Proses komunikasi dimana sumber (kandidat atau partai) membeli space untuk mengekspos atau menyebarkan sesuatu melalui pesan dengan maksud untuk mempengaruhi sikap politik, keyakinan, dan atau tingkah laku mereka". (Kaid: 2004, 156).

Dari pemaparan diatas dapat diuraikan bahwa iklan politik adalah proses komunikasi politik yang dilakukan oleh seorang politikus atau kandidat untuk menyampaikan gagasanya guna meraih dukungan publik yang sebesar-besarnya melalui sebuah iklan. 
Diterbitkan oleh Fakultas Sastra dan Budaya

Universitas Ahmad Dahlan Yogyakarta

Sejarah iklan politik sendiri berawal pada tahun 1948. Rosser Reeves, seorang pimpinan eksekutif dari biro iklan Ted Bates dan merupakan tokoh berpengaruh di bidang periklanan. Dia menjadi pendukung Thomas E. Dewey, gubernur New York yang maju menjadi kandidat presiden dari Partai Republik. Reeves melihat iklan sebagai sarana persuasif di televisi dan bisa menjual produk serta jasa sehari-hari. Diasumsikan bahwa iklan juga bisa digunakan untuk mempromosikan politisi. Namun Dewey menolak. Karena merasa layar TV tersebut dianggap tidak tepat. Padahal disisi lain Bruce Barton, Batten, Durstine \& Osborn (BBDO), juga tertarik dalam membantu Dewey. (Brian Cogan dan Tony Kelso, 2009: 140).

Pada awal 1950-an, televisi telah menjadi media yang berkembang secara pesat di Amerika Serikat. Hal ini didukung oleh pendapatan finansial dari iklan. Pada tahun 1952 dalam kampanye presiden AS, Jenderal Eisenhower, menjadi kandidat pertama yang mempekerjakan sebuah perusahaan periklanan secara profesional untuk merancang iklan politik di televisi. Saat itu menghabiskan dana kurang lebih \$ 1.000.000. Konsultan politik dari Batten, Barton, Dustine, dan Osbourne dipilih untuk merancang kampanye tersebut, sementara konsultan Rosser Reeves membantu merumuskan Eisenhower dalam mendesain isi iklan, (McNair, 2011: 90-91).

Selama kampanye presiden 1952, tampak bahwa partai Demokrat, yang dipimpin oleh Adlai Stevenson, gelisah dan meminta bantuan Madison Avenue untuk menandingi sepak terjang Eisenhower. Beberapa tema dalam iklan Stevenson termasuk berani dalam menyerang lawan politiknya. Misalnya tema yang diangkat, kurangnya pengalaman politik lawan dari partai Republik, Jenderal Dwight D. Eisenhower; Eisenhower berhubungan dengan pejuang anti Komunis Senator Joseph McCarthy; Eisenhower merupakan ancaman kepemimpinan Republik dimana warga negara akan tenggelam ke dalam depresi; dan Stevenson adalah seorang kandidat tempat menaruh harapan yang akan menyelesaikan masalah rakyat Amerika. Di sisi lain, Eisenhower merupakan kandidat yang pertama berhasil menunjukkan efektivitas iklan politik di televisi, salahsatunya iklan dengan tema, "Soon to be Presiden Eisenhower". Dalam pelaksanaanya, Eisenhower membuat sebuah lembaga, yang akhirnya menghasilkan program TV, iklan, dan berhubungan dengan studio Disney, perusahaan film kartun yang menampilkan sebuah jingle, "I Like Ike". Dari situ, pendukung Eisenhower percaya ia memiliki kepribadian yang menyenangkan yang akan tampil dengan baik pada media baru. Beberapa pengamat menduga bahwa pesonanya bisa lebih baik jika disampaikan melalui iklan pendek, dengan penampilan kasual yang penuh perasaan daripada pidato formal. (lihat Lilleker, 2006 :96)

Kemudian, Rosser Reeves bekerjasama dengan Michael Levin, seorang karyawan dari Erwin, Wasey \& Co. Mereka merancang strategi iklan yang menekankan kesederhanaan. Tidak seperti Stevenson, yang jarang muncul dalam iklan kampanyenya. Serangkaian iklan kampanye dibuat, seperti "Eisenhower Jawaban America". Sementara Stevenson maju dengan slogan kampanye, "Your Never Had It So Good!'. Tim Eisenhower membalas dengan "Saatnya untuk Perubahan". Mengingat Partai Demokrat begitu kreatif dalam iklan kampanye, Partai Republik juga menggunakan televisi sebagai tambahan, seperti broadcast pidato, drama, dan acara politik lainnya untuk kampanye. Reeves dan para pengamat menyimpulkan, bahwa Eisenhower akan menang bahkan jika mereka tidak mengembangkan iklan sekalipun. Pada tahun 1952, sebuah jajak pendapat yang dilakukan 
oleh Roper, bahwa Eisenhower adalah kandidat yang paling dikagumi di Amerika. Selain itu, ditahun 1952 kampanye yang dilakukan oleh kedua belah pihak menandai berakhirnya bentuk kampanye dengan pidato panjang yang ditayangkan di televisi dan menggantinya dalam format yang lebih pendek, terutama spot iklan di TV. (Brian Cogan dan Tony Kelso, 2009: 141-142)

Selanjutnya iklan politik yang dimulai Amerika berkembang kedaratan Eropa dan akhirnya meluas keseluruh penjuru dunia, termasuk Indonesia.

Iklan, termasuk didalamnya iklan politik (kampanye) memiliki kelebihan tersendiri, khususnya bila dibandingkan dengan berita dalam konteks sosialisasi dan memperkenalkan seorang kandidat. Kelebihan atau kekuatan iklan yang pertama adalah iklan politik menyebarkan informasi tentang seorang kandidat atau partai dimana hal tersebut sangat jarang sesuai dengan keinginan jurnalis. Artinya hal-hal yang tidak ditangkap oleh seorang jurnalis bisa di munculkan dalam iklan tersebut. Kedua, kontrol iklan terletak pada editor dan sang kandidat, bukan pada media. Hal ini memudahkan dalam menyampaikan pesan, mempersuasi dimana jarang terjadi pada pada sebuah berita, (McNair, 2011: 85-86).

Dalam implementasinya, iklan berjalan dengan beberapa fase. Diamond dan Bates dalam McNair (2011: 99) mengidentifikasi ada empat fase iklan politik. Pertama, identitas calon harus ditetapkan sebagai landasan untuk membangun informasi selanjutnya. Pada fase ini, detail biografi yang baik dan bernilai positif disorot. Artinya prestasi, kehidupan pribadi yang menonjol dan baik disampaikan ke publik. Kedua, memblowup kebijakan calon yang akan diusung jika terpilih dengan detail dan dengan muatan emosional. Ketiga, lawan harus diserang, walaupun itu merupakan aib atau keburukan dan kelemahan. Dan keempat, calon harus dicitrakan dengan makna positif dalam konteks nilai-nilai yang disesuaikan dengan aspirasi pemilih. Pada fase ini kampanye akan berusaha untuk mensintesis dan mengintegrasikan fitur positif kandidat, sehingga sang kandidat atau partai diharapkan mendapatkan resonansi di benak pemilih.

Iklan politik seperti halnya iklan produk barang dan jasa adalah hasil konstruksi realitas. Ini karena iklan politik menjadi bagian atau masuk dalam pemasaran politik. Iklan berusaha mengubah peristiwa semu menjadi kejadian riil sehari-hari. Oleh karena sifatnya yang merupakan rekaan itu, iklan politik mempunyai peran yang signifikan, utamanya dalam mengkonstruksikan kandidat. Dari konstruksi itu, kemudian, bisa dibangun suatu citra tertentu. Seperti halnya iklan produk-produk kecantikan, iklan politik juga bisa membangun suatu citra tertentu. Dalam hal ini, pesan iklan politik tidak sekedar 'pokoknya populer', tetapi popular dengan citra tertentu. Para kandidat beriklan untuk menyatakan eksistensi diri mereka. Iklan politik di media massa sifatnya memang satu arah dan layaknya produksi di media massa, iklan politik dibentuk sedemikian rupa untuk menampilkan pencitraan kandidat dengan narasi dan ilustrasi yang dibuat secara menarik dan seolah-olah dekat dengan masyarakat yang juga diikutsertakan dalam iklan kampanye politik tersebut serta peduli dengan isu-isu yang dijadikan andalan meskipun pada kenyataan masih diper-tanyakan. Di sisi lain, Iklan kampanye politik di media massa mungkin menimbulkan kesan terbiasa (familiarity) akan sosok yang diangkat. Karena orang yang paling bayak menerima pesan adalah orang yang cenderung untuk mengerti (Nimmo: 2010, 162). 
Diterbitkan oleh Fakultas Sastra dan Budaya

Universitas Ahmad Dahlan Yogyakarta

Tidak bisa dipungkiri bahwa iklan politik mampu membangun citra yang positif bagi kandidat. Meskipun seberapa efektif suatu iklan dalam memengaruhi pemilih masih menjadi tanda tanya. Melalui kampanye dan iklan politik, dampak-dampak kampanye politik dan media berada dalam hubungan yang kompleks, tidak semata-mata terbatas pada bagaimana kualitas dan kuantitas pesan dirancang, tapi melibatkan pula konteks sosio-kultural dan relasi-relasi kekuasaan.

Dalam iklan politik, biasanya terdiri dari tiga macam kategori. Yaitu, jenis iklan positif, komparatif dan menyerang. Iklan positif adalah jenis iklan dengan menyampaikan keunggulan dari kontestan. Adapun iklan komparatif adalah jenis iklan yang mengambarkan diferensiasi antar kontestan. Adapun jenis iklan menyerang dilakukan dengan mengemukakan kelemahan-kelemahan lawan politiknya. (Nursal, 2004: 243). Sehingga iklan kemudian dijadikan oleh seorang kandidat untuk melakukan kampanye politik pencitraan, yaitu untuk membangun kesan dalam diri masyarakat sehingga tampil dengan hal-hal positif.

Darren G. Lilleker, (2006:96) mengutip Arthur Sanders, seorang ahli dalam penggunaan iklan dan media di Amerika Serikat, berpendapat bahwa iklan politik yang sukses harus menunjukkan empat fitur. Mereka harus:

1. Memiliki dampak yang dramatis.

2. Menarik pada tema-tema, cerita dan genre yang relevan.

3. Fokus pada orang, sering orang yang nyata dan bukan politisi atau pelaku, bukan dari kebijakan.

4. Sederhana, sehingga membawa satu pesan mudah dipahami.

Adapun pengaruh iklan terhadap pemilih menurut Lynda Lee Kaid (2004: 167171) terdapat tiga hal, yaitu pengetahuan pemilih, persepsi terhadap kontestan dan preferensi pilihan. Perngaruh pertama untuk mengidentifikasi nama kandidat atau kontestan lebih mudah, karena pesan yang disampaikan dalam iklan walau singkat tetapi padat dengan isi pesan. Pendaruh kedua adalah efek dari hasil evaluasi terhadap kandidat atau kontestan. Iklan televisi member dampak signifikan terhadap tingkat kesukaan terhadap seorang kandidat khususnya kebijakan yang akan dilakukan jika terpilih. Pengaruh ketiga adalah pemberian preferensi pilihan. Hal ini dikarenakan dalam iklan terdapat variabel penting yang mempengaruhi preferensi, yaitu formasi citra dan tingkat awareness para pemilih.

Nilai-nilai artistik yang mutlak dimiliki sebuah iklan membutuhkan sebuah pengkondisian dan reproduksi kesadaran yang terus menerus melalui manipulasi simbolsimbol sehingga pesan yang dibawa iklan bisa tercapai dengan cara yang sangat halus. Iklan politik sebagai media yang memiliki misi untuk memberikan pencitraan yang bersifat komersil terhadap sesuatu produk mutlak memiliki nilai-nilai artistik yang mengundang ketertarikan khalayak (konsumen), paling tidak perhatian tehadap iklan tersebut. Selanjutnya masyarakat diharapkan menyukai produk yang ditawarkan dan tahap terakhir adalah memilih produk tersebut, (Piliang, 2012: 130-135). 


\section{Metodologi Penelitian}

Analisis penelitian kualitatif bersifat induktif, artinya bahwa simpulan dibentuk dari semua informasi yang bersifat khusus menuju yang bersifat umum, (Creswell, 2010: 4). Proses analisis ini dilakukan bersamaan sejak awal dengan proses pengumpulan data. Setiap data yang diperoleh akan selalu dikomparasikan, setiap unit atau kelompoknya untuk melihat keterkaitannya sesuai dengan tujuan penelitian.

Teknik analisis dan penafsiran data dalam penelitian ini dilakukan dengan menelaah seluruh data iklan yang tersedia, dalam hal ini adalah dari iklan kampanye pemilu presiden 2009 yang berjumlah 4 buah dengan perincian, pasangan MegaPrabowo (Kenaikan harga dan Bangkrut), pasangan SBY-Budiono (Dari Sabang sampai Merauke dan Dari rakyat untuk rakyat). Setelah ditelaah maka langkah selanjutnya adalah mengadakan reduksi data dengan cara menginterpretasikan teks iklan guna mengungkap makna kontekstual. Diakhiri dengan penafsiran data, dengan cara melihat keseluruhan iklan dan lebih khusus pada konteks politik identitas yang ditonjolkan dalam iklan, dengan mengaitkan konteks masyarakat saat itu yang melatarbelakanginya, mencakup konteks sejarah, sosial, politik dan budaya.

\section{Pembahasan}

\section{Profil Pasangan Calon Presiden}

a. Megawati Sorkarno Putri berpasangan dengan Prabowo Subianto atau disingkat pasangan (Mega-Pro).

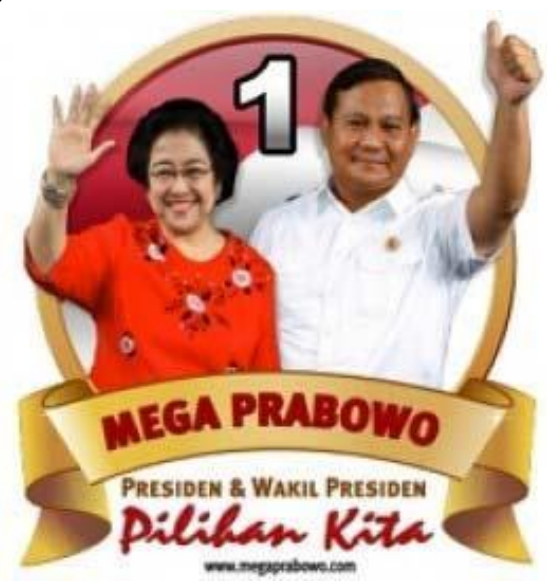

Gambar 1. Logo pasangan Mega-Prabowo

Calon presiden Megawati merupakan salah satu putra proklamator Indonesia yang juga presiden pertama, Soekarno atau yang lebih sering disapa sebagai Bung Karno. Megawati lahir 23 Januari 2947, dengan nama Dyah Permata Megawati Setyawati Soekarnoputri. Sehingga pada pemilu tahun 2009 usianya mencapai 62 tahun. Tidak ada hal yang spesial dalam diri Megawati dimasa mudanya. Sempat mengenyam bangku perguruan tinggi di fakultas pertanian Universitas Parahiyangan, Bandung. Sempat pula aktif di organisasi kemahasiswaan, GMNI (Gerakan Mahasiswa Nasional Indonesia), 
Diterbitkan oleh Fakultas Sastra dan Budaya

Universitas Ahmad Dahlan Yogyakarta

(Thoha, 2009: 40). Megawati memang tidak banyak berkiprah dalam perpolitikan Indonesia pada masa orde baru, mengingat mantan Presiden Soeharto sangat membatasi kiprah dari lawan politiknya (Soekarno dan anak keturunanya) tersebut.

Partai PDI yang dipimpin oleh Suryadi melihat potensi keluarga Soekarno bisa mendongkrak suara dalam pemilu, maka Megawati ditarik masuk menjadi anggota partai PDI. Itulah titik balik Megawati yang mulai memasuki ranah politik, namun sampai disitu popularitas Megawati belum juga terdongkrak. Sampai pada kongres PDI ditahun 1993, di mana mayoritas memilih Megawati untuk menjadi ketua umum PDI, namun Suryadi atas desakan Presiden Soeharto memilih Budi Harjono sebagai ketua karatecker. Akhirnya terjadi insiden penyerangan 27 Juli 1996, yang menyebabkan kubu Suryadi/Budi Harjono dan Megawati berebut kantor pusat PDI sampai menelan korban jiwa. Berawal dari kejadian tersebut, Megawati mendirikan partai sendiri yang diberi nama PDI-Perjuangan. (Darmawan, 2004: 79-152). Karir Megawati semakin bersinar manakala Soeharto lengser. Pada pemilu 1999, PDIP menjadi partai pemenang pemilu dan menempatkan Megawati sebagai wakil presiden mendampingi Gus Dur. Setelah Gus Dur dilengserkan oleh sidang istimewa MPR, Megawati naik menjadi presiden didampingi Hamzah Haz.

Adapun calon wakil presiden pasangan Megawati adalah Prabowo Subianto. Dia adalah anak begawan ekonomi Soemitro Djoyohadikusumo dan juga menantu dari penguasa orde baru, presiden Soeharto. Prabowo lahir 17 Oktober 1951, (Soempeno, 2008 : 170). Masa kecil Prabowo memang lebih banyak dihabiskan di luar negeri seperti Singapura tiga tahun, Malaysia dua tahun, Hong Kong dua tahun, Swis dua tahun, Inggris dua tahun. Di Inggris inilah Prabowo menyelesaikan sekolah menengahnya. Prabowo menyelesaikan bangku sekolah menengahnya pada usia 16 tahun di American School London, Inggris. Selanjutnya, Prabowo masuk AKABRI di Magelang. Karir kemiliterannya bisa dibilang cukup cemerlang, konon hal ini disebabkan karena Prabowo adalah menantu dari presiden Soeharto. Jabatan Denjan Kopassus dan Pangkostrad pernah dipegangnya. Karir militernya berakhir ketika revormasi 1998 bergulir, dia dianggap bertanggungjawab atas penculikan yang dilakukan oleh tim mawar Kopassus yang berakibat hilangnya sejumlah aktifis serta dituduh akan melakukan kudeta. Namun hal ini telah dibantahnya. Setelah Jendral Wiranto mencopotnya dari dinas kemiliteran, Prabowo pergi ke Yordania. Di sana dia mulai merintis bisnis. Dan pada tahun 2004 ketika pemilu akan berlangsung, Prabowo kembali ke Indonesia dan ikut dalam konvensi calon presiden dari partai Golkar yang akhirnya kalah, Wiranto yang menjadi pemenangnya. Pada tanggal 6 Februari 2008, Prabowo resmi mendirikan partai Gerindra yang akan dijadikan kendaraannya dalam berpolitik. (Soempeno, 2008: 109181)

Pasangan ini diusulkan oleh koalisi dari PDIP, Partai Gerindra, PNI Marhaenisme, Partai Buruh, Partai Merdeka, Partai Kedaulatan, PSI dan PPNUI dengan jumlah presentasi kursi di DPR-RI sebanyak 21,61\%. Dengan jumlah kekayaan yang dimiliki oleh Megawati sebesar 256,5 milyar sedangkan Prabowo memiliki kekayaan sebesar 1,6 trilyun membuat pasangan ini memiliki kekayaan terbanyak. Pasangan Megawati-Prabowo mengangkat Visi: Gotong Royong membangun kembali Indonesia Raya yang berdaulat, bermartabat dan makmur. Adapun Misi yang diusung oleh pasangan ini adalah:

a. Menegakkan kedaulatan dan kepribadian bangsa yang bermartabat.

b. Mewujudkan kesejahteraan social dengan memperkuat ekonomi kerakyatan. 
c. Menyelenggarakan pemerintahan yang tegas dan efektif.

Sedangkan agenda pokok yang dikedepankan dalam membangun kembali Indonesia Raya:

a. Kekayaan Negara untuk kemakmuran rakyat.

b. Meaksanakan ekonomi kerakyatan.

c. Membangun kedaulatan pangan dan energi.

d. Menyelenggarakan pemerintah yang tegas, bersih dan efektif dalam melayani rakyat.

e. Menciptakan manusia Indonesia yang unggul, sehat, dan berkepribadian melalui pendidikan, kesehatan, dan kebudayaan. (Sumber, Kompas 2 Juni 2009).

b. Susilo Bambang Yudhoyono berpasangan dengan Budiono atau disingkat pasangan (SBY-Berbudi).

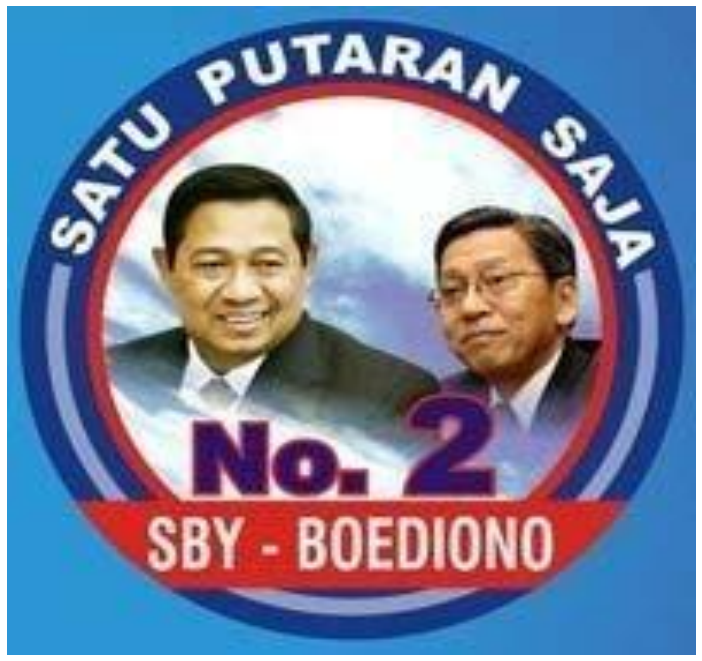

Gambar 2. Logo pasangan SBY-Budiono

Susilo Bambang Yudhoyono atau yang biasa dipanggil dengan SBY, lahir di Pacitan, Jawa Timur. SBY terlahir dari keluarga biasa, ayahnya adalah seorang tentara yang berpangkat rendah dan ibunya adalah seorang ibu rumah tangga. Masa kecil dan pendidikan dasarnya SBY dilalui di kampung halamannya. Terlahir dari keluarga militer, membuat SBY juga ingin berkarir di militer seperti ayahnya. Ayahnya pada tahun 1970 mengirim SBY mendaftar AKABRI di Magelang dan diterima, akhirnya SBY lulus tahun 1973 dengan mendapat predikat lulusan terbaik. Melihat kecerdasan SBY, mantan Gubernur AKABRI yang juga mantan komandan RPKAD di tahun 1965, Letjen Sarwo Edhi Wibowo mengambilnya sebagai menantu. SBY menikah dengan Kristiani Herawati. Karir militernya terbilang cukup cemerlang, walau tak secemerlang Prabowo. SBY tercatat sebagai pangdam termuda di Indonesia, saat itu usiannya baru 47 tahun. Karena kegeniusannya, SBY disebutsebut sebagai intelektualnya TNI, hasilnya adalah SBY didaulat untuk merumuskan revormasi ditubuh TNI. Berbagai jabatan mentereng pun disandangnya, pada masa presiden Abdurrahman Wahid pernah menjabat menteri 
Diterbitkan oleh Fakultas Sastra dan Budaya

Universitas Ahmad Dahlan Yogyakarta

Pertambangan dan Energy dan menjadi menteri Polsoskam. Adapun pada masa presiden Megawati, SBY menjabat sebagai menko Polhukam. Saat menjabat Menko Polhukan inilah popularitas dan elektabilitas SBY mulai naik. Hal ini salah satunya dipicu oleh perseteruannya dengan Megawati menjelang pemilu 2004 yang menempatkannya sebagai sosok yang tertindas. Akhirnya SBY mendirikan partai Demokrat pada 9 September 2002 sebagai kendaraannya maju pilpres tahun 2004. (Darmawan, 2004: 231-308).

Pasangan SBY dalam pemilu presiden adalah Boediono. Dia lahir di Blitar, Jawa Timur, pada tanggal 25 Februari 1943. Menamatkan pendidikan dasar dari SD sampai SMA di tempat kelahirannya. Pada 1967, ia memperoleh gelar Bachelor of Economics (Hons.) dari Universitas Western Australia. Karir akademiknya cukup cemerlang. Mendapat gelar Master of Economics dari Universitas Monash. Kemudian pada tahun 1979, ia mendapatkan gelar S3 (Ph.D.) dalam bidang ekonomi dari Wharton School, Universitas Pennsylvania, Amerika Serikat. Istrinya bernama Herawati dan dianugerahi dua orang anak, Retrina Ekarini dan Dios Kurniawan. (budionomendengar.com: 2014).

Budiono mengabdikan dirinya menjadi dosen di Fakultas Ekonomi Universitas Gadjah Mada, di universitas ini pula ia diangkat sebagai Guru Besar pada Februari 2007. Budiono terkenal sebagai seorang yang tenang, murah senyum dan bekerja dengan tekun. Boediono pertama kali diangkat menjadi Menteri pada 1998 dalam Kabinet Reformasi Pembangunan sebagai Menteri Negara Perencanaan Pembangunan Nasional pada masa pemerintahan Presiden BJ Habibie. Pada masa pemerintahan Presiden Megawati Sukarnoputri diangkat kembali Menjadi menteri Keuangan Indonesia dalam Kabinet Gotong Royong (2001-2004) mengantikan Rizal Ramli. Sempat istirahat menjadi Menteri, satu tahun kemudian dipanggil SBY sebagai Menko Perekonomian pada Kabinet Indonesia Bersatu (5 Desember 2005-17 Mei 2008), mengantikan Abu Rizal Bakri. Selanjutnya, 17 Mei 2008 - 17 Mei 2009, Budiono di tugaskan oleh SBY menjabat sebagai Gubernur Bank Indonesia. (wapres.go.id: 2014).

Salah satu prestasi Budiono ketika menjabat di birokrasi, dia berhasil membawa Indonesia lepas dari bantuan Dana Moneter Internasional dan mengakhiri kerjasama dengan lembaga tersebut. Dari prestasinya tersebut, majalah Business Week, memandangnya sebagai salah seorang menteri yang paling berprestasi dalam kabinet tersebut. Budiono juga berhasil menstabilkan kurs rupiah di angka kisaran Rp 9.000 per dolar AS. (budionomendengar.com:2014).

Pada tanggal 17 Mei 2009, Budiono resmi mengundurkan diri dari Gubernur Bank Indonesia. Boediono dilamar SBY menjadi calon wakil presiden untuk periode 2009-2014. Mereka mendeklarasikan diri pada 15 Mei 2009 di Sasana Budaya Ganesha kota Bandung.

Pasangan ini diusulkan oleh koalisi dari partai Demokrat, PKS, PAN, PPP, PKB, PBB, PDS, PPKB, PBR, PPRN, PKPI, PDP, PPPI, Partai Republikan, Partai Patriot, PNBKI, PMB, PPI, Partai Pelopor, PKDI, PSI, PIB, PDI. Dengan presentasi jumlah kursi di DPR RI sebanyak 56,07\%. Adapun jumlah kekayaan yang dimiliki oleh SBY sebesar 6,86 milyar sedangkan Budiono memiliki kekayaan sebesar 22,1 milyar. Visi yang diangkat adalah: Terwujudnya Indonesia yang sejahtera, demokratis, dan berkeadilan. Adapun Misi pasangan ini adalah:

a. Melanjutkan pembangunan menuju Indonesia yang sejahtera.

b. Memperkuat pilar-pilar demokrasi. 
c. Memperkuat dimensi keadilan di semua bidang.

Sedangkan agenda utama dalam Pembangunan Nasional 2009-2014:

a. Pembangunan ekonomi dan peningkatan kesejahteraan rakyat.

b. Perbaikan tata kelola pemerintah.

c. Penegakkan Pilar Demokrasi.

d. Penegakkan hukum dan pemberantasan korupsi.

e. Pembangunan yang inklusif dan berkeadilan.

\section{Interpretasi Makna Iklan Sebagai Politik Identitas}

1. Mega-Prabowo

a) Naiknya Harga

Iklan ini berdurasi 60 detik yang bercerita bahwa selama kepemimpinan lima tahun sebelumnya, harga bahan pokok cenderung naik, dan solusinya untuk menurunkan adalah jika kepemimpinan ada ditangan Mega-Prabowo.

Iklan ini dimulai dengan ilustrasi voice over, "Tingginya harga sangat menyengsarakan kita semua, setiap pagi para pekerja tidak bisa membeli BBM dan transportasi, uang mereka terus menipis, setiap malam kekurangan pangan". Kalimat tersebut ingin meberi penegasan bahwa kondisi masyarakat dalam keadaan sengsara dan susah karena tidak bisa membeli BBM. Karena harga BBM yang tidak terjangkau maka uang yang seharusnya untuk membeli makan terkuras guna membeli BBM.

Dalam iklan ini, suara ilustrator dilanjutkan dengan kalimat, "Sementara pemerintah berkata bahwa ekonomi kita kuat, BBM dan pangan jauh lebih murah". Di sini Mega-Prabowo ingin membandingkan antara realitas yang terjadi di masyarakat dengan klaim dari pemerintahan SBY. Realitas menunjukan masyarakat dirundung kesusahan, akan tetapi pemerintah mengklaim BBM murah dan ekonomi pemerintahan kuat. Sebuah kondisi perbedaan klaim, tentu tidak aneh terjadi sebuah perbedaan. Dikarenakan kondisi yang baik akan menguntungkan siapa yang mengklaim.

Voice over melanjutkan kalimatnya, "Kenyataannya setelah lima tahun hanya janji kosong belaka, sembako hampir 50\% lebih tinggi dari tahun 2004". Kalimat dari voice over ini diikuti dengan gambar dibawah ini.

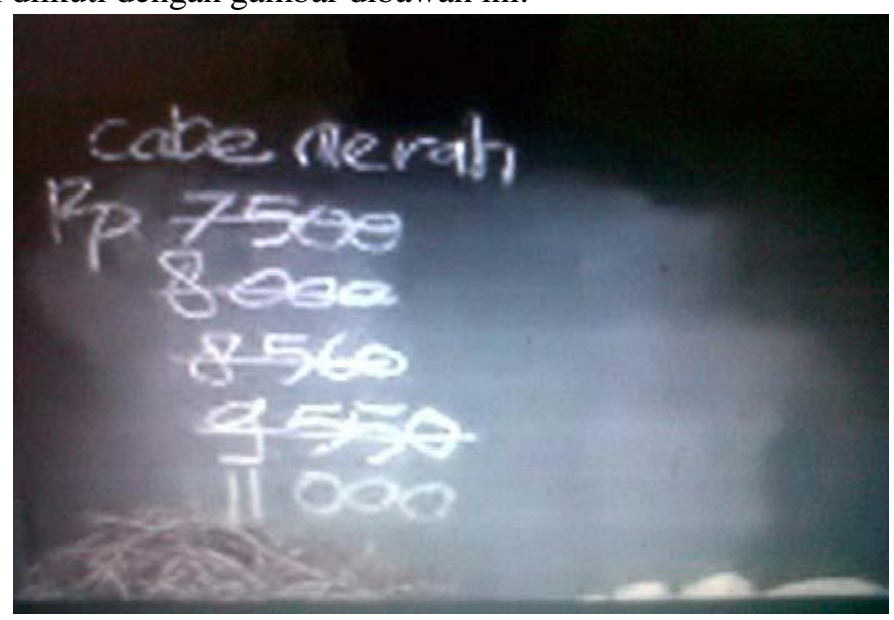

Gambar 3. Ilustrasi naiknya harga sembako 
Diterbitkan oleh Fakultas Sastra dan Budaya

Universitas Ahmad Dahlan Yogyakarta

Dari kalimat dan gambar tersebut, Mega-Prabowo ingin memberi penegasan bahwa faktanya harga-harga sembako cenderung naik. Gambar papan tulis dengan harga cabe yang cenderung naik merupakan justifikasi pasangan ini terkait naiknya harga. Padahal disisi lain, dengan kenaikan inflasi dan melemahnya nilai tukar rupiah sangat berpengaruh dengan nominal nilai rupiah.

Iklan ini dilanjutkan dengan ilustrasi suara "Kita tak bisa hanya makan janji, saatnya perubahan". Dengan gambar latar menunjukan warga miskin yang meratapi anaknya yang sedang sakit.

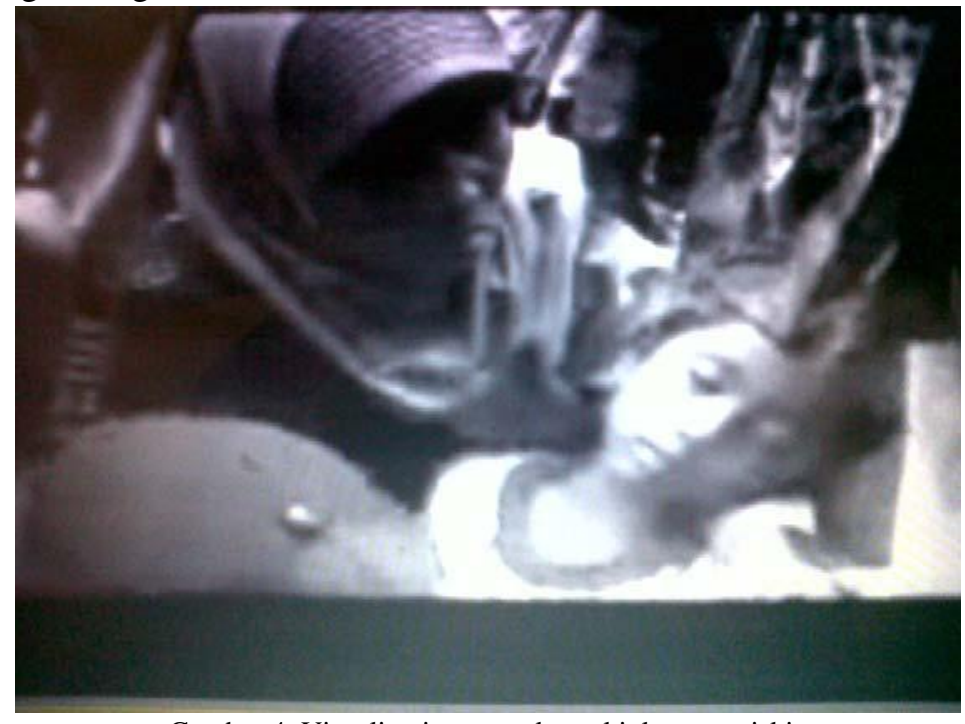

Gambar 4. Visualisasi masyarakat sakit karena miskin

Antara kalimat yang disampaikan oleh voice over dengan gambar iklan, pasangan ini ingin memberi kesan bahwa gambar perempuan miskin dengan anaknya yang tergeletak dipangkuannya merupakan simbol kemiskinan, kelemahan, kebijakan yang tidak tepat sasaran maupun pemerintah yang abai pada rakyatnya. Mega-Prabowo berkeinginan memberantas itu semua dengan memberi keyakinan akan adanya perubahan jika pasangan ini terpilih. Perubahan yang lebih baik dan mensejahterakan tentunya. Iklan ini dilanjutkan dengan gambar Megawati sedang tertawa bersama para pedagang di pasar. 


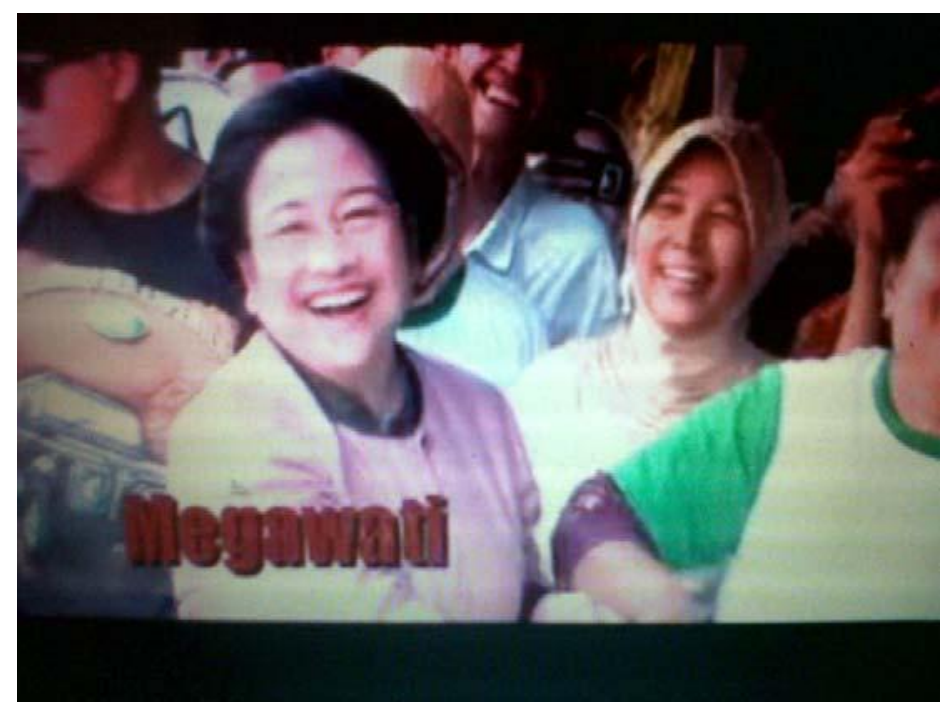

Gambar 5. Visualisasi kedekatan Megawati dengan rakyat

Pasangan ini ingin menegaskan jika terpilih, kondisi masarakat akan berubah menjadi sejahtera. Hal ini ditunjukan dengan senyum Mega dan para pedagang. Secara umum simbol senyum merupakan pertanda kebahagiaan. Namun tangis juga bisa menunjukan ekspresi kebahagiaan. Bahkan tangis karena terharu merupakan ujung dari nilai kebahagiaan itu sendiri.

Sesaat kemudian muncul Megawati dan Prabowo yang diiringi oleh pendukungnya dari belakang. Megawati dan Prabowo berjalan dengan pakaian khas seperti yang dikenakan oleh Sukarno.

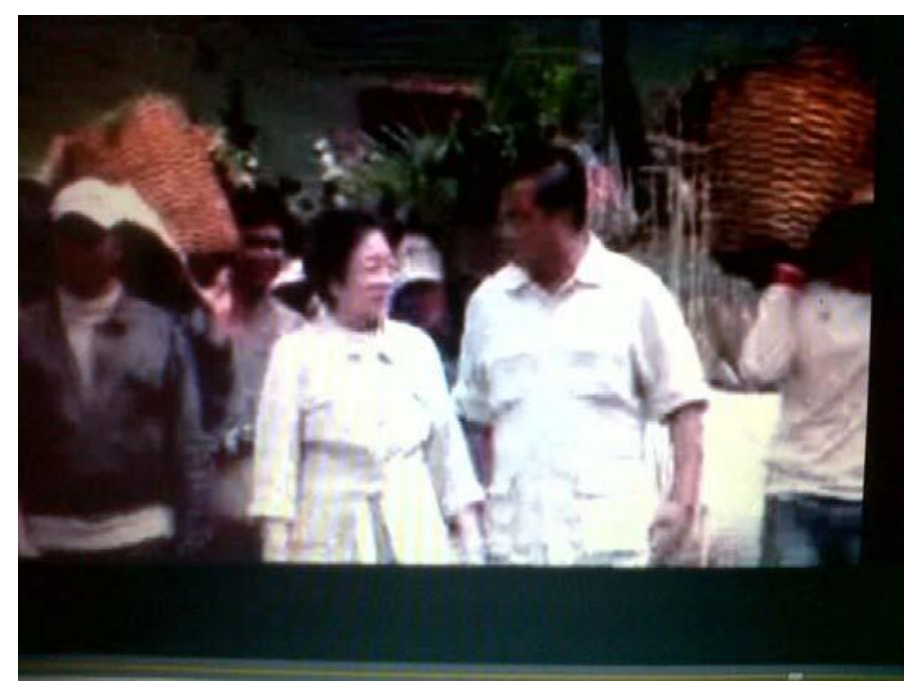

Gambar 6. Visualisasi Mega-Prabowo dengan rakyat 
Diterbitkan oleh Fakultas Sastra dan Budaya

Universitas Ahmad Dahlan Yogyakarta

Bila dicermati dengan seksama betuk pakaian yang dikenakan Mega dan Prabowo seperti yang dikenakan oleh Bung Karno tentu memiliki tujuan tertentu. Sosok Soekarno yang kharismatik sebagai orator ulung sehingga mampu menghipnotis rakyat akan sulit disamakan dengan putrinya Megawati. Tentu konsep pakaian tidak bisa mencerminkan posisi intelektual seseorang, namun ketika orang yang berpakaian dengan cirri khas seperti Soekarno yang mempunyai posisi intelektual memadai, maka hal apa yang melekat pada orang tersebut akan ditiru agar dianggap mempunyai kesamaan.

Jika dipersepsikan bahwa seorang pemimpin harus mempunyai fisik yang kuat dan gagah tentu tidak ada urgensinya. Banyak contoh pemimpin yang mempunyai fisik tidak kuat, semisal Nelson Mandela maupun Mahatma Gandi yang senantiasa membawa tongkat namun dapat memimpin dengan bagus. Namun jika kuat dan gagah yang dimaksud adalah kuat hati untuk menerima kritik dan kharismatik dalam memimpin rakyat tentu hal itu adalah sah-sah saja.

Dalam iklan ini muncul ketika kalimat voice over, "Mega-Prabowo. Ibu negara yang di masa kepemimpinannya mampu membuat harga sembako dan minyak tanak murah". Pasangan ini ingin mempersepsikan seolah dimasa pemerintahan Megawati tahun 2001-2004 harga-harga lebih murah bila di banding tahun 2009. Tentu secara nominal lebih murah, tetapi hal tersebut sangat dipengaruhi oleh nilai rupiah yang memang terus melemah.

Iklan ini diakhiri dengan gambar Mega-Prabowo yang bergandengan tangan dengan ilustrasi suara "Mega-Prabowo, pro keluarga, pro rakyat". Dari semua rangkaian iklan, pasangan ini menegaskan bahwa mereka yang pro terhadap kepentingan rakyat, yang mengerti keinginan dan menjadi solusi dari masalah fundamental rakyat.

\section{b) Bangkrut}

Iklan yang berdurasi 60 detik ini diawali dengan visualisasi Megawati dengan berbaju merah sedang berjabat tangan dan bercengkrama dengan sekerumunan rakyat kecil, dilanjutkan dengan gambar Prabowo dengan pakaian khas seperti yang dikenakan Soekarno, sedang mengajar anak-anak SD.

Suara dari voice over, "Pesan dari Mega-Prabowo, selama setahun kami mengajak saudara-saudara untuk membeli produk Indonesia. Dari para petani, nelayan, pemilik warung dan buruh". Yang diikuti oleh visualisasi gambar suasana toko kelontong seperti pada gambar dibawah. 


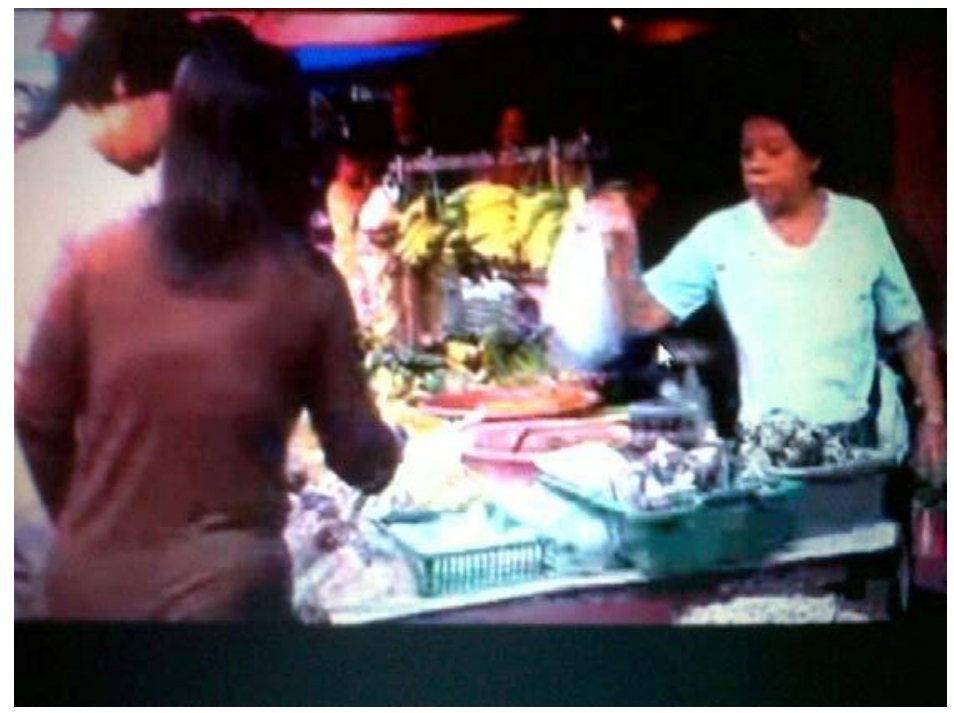

Gambar 7. Kondisi pasar sebagai cermin pertumbuhan ekonomi

Ada satu hal yang perlu dicermati, bahwa sudah hampir satu tahun pasangan ini mengajak masyarakat untuk membeli produk dalam negeri melalui. Artinya dalam forum resmi, pemberitaan maupun iklan pasangan ini telah mengajak rakyat. Kedua, pasangan ini merasa bahwa produk lokal kurang diperhatikan. Banyak produk impor, mulai dari bahan makanan pokok sampai elektronik. Semisal, daging impor dari Australia, beras dari Thailand dan Vietnam, elektronik dari Jepang, Korea, China dan masih banyak lagi. Mega-Prabowo mengunakan isu ini untuk menggugah hati masyarakat.

Muncul suara "Di bawah pemerintahan ini, Indonesia tenggelam di bawah lautan utang, sejak 2004 utang terus meningkat, kini 7 juta rupiah untuk setiap orang menanggung utang".

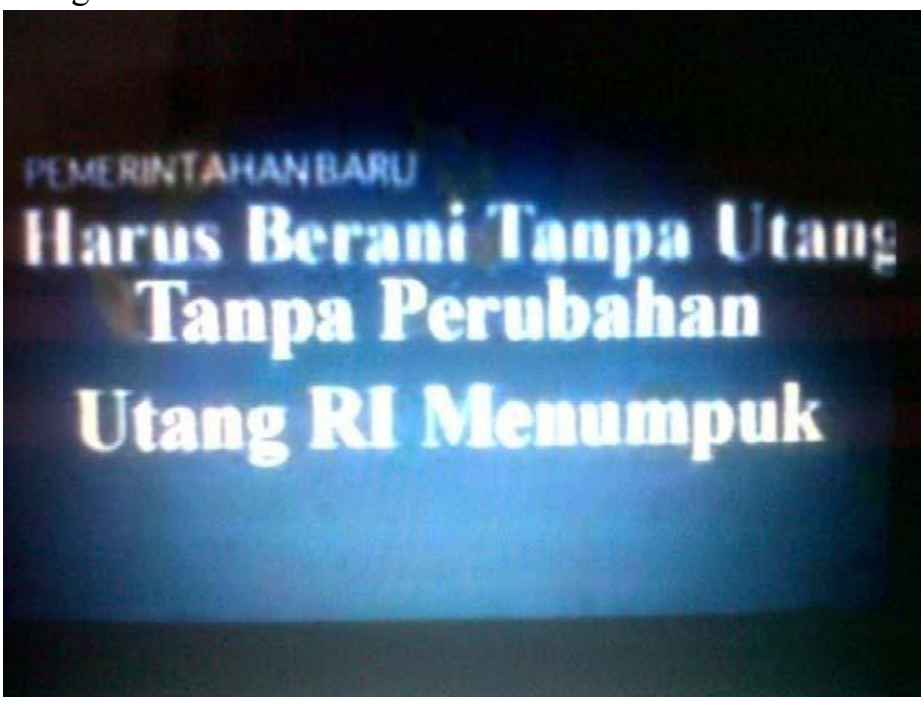

Gambar 8. Visualisasi kalimat penegas agar pemerintah mendatang tidak menambah hutang. 
Diterbitkan oleh Fakultas Sastra dan Budaya

Universitas Ahmad Dahlan Yogyakarta

Pasangan ini memang memiliki tim yang cerdik untuk membuat sebuah iklan dengan menunjukan data mengenai kelemahan SBY selaku incumbent. Tentu data sangat penting ditampilkan untuk membangun rasio masyarakat. Ditegaskan bahwa pemerintahan SBY dari 2004-2009 berlumuran dengan hutang. Dan utang itu terus meningkat. Pasangan ini berani untuk membuat pemerintahan ke depan tidak mempunyai hutang. Dalam iklan tersebut, ditegaskan bahwa utang negara sekarang ini jika dibebankan pada seluruh rakyat, maka akan ketemu 7 juta rupiah untuk setiap orang. Sebagaimana di gambar dibawah ini.

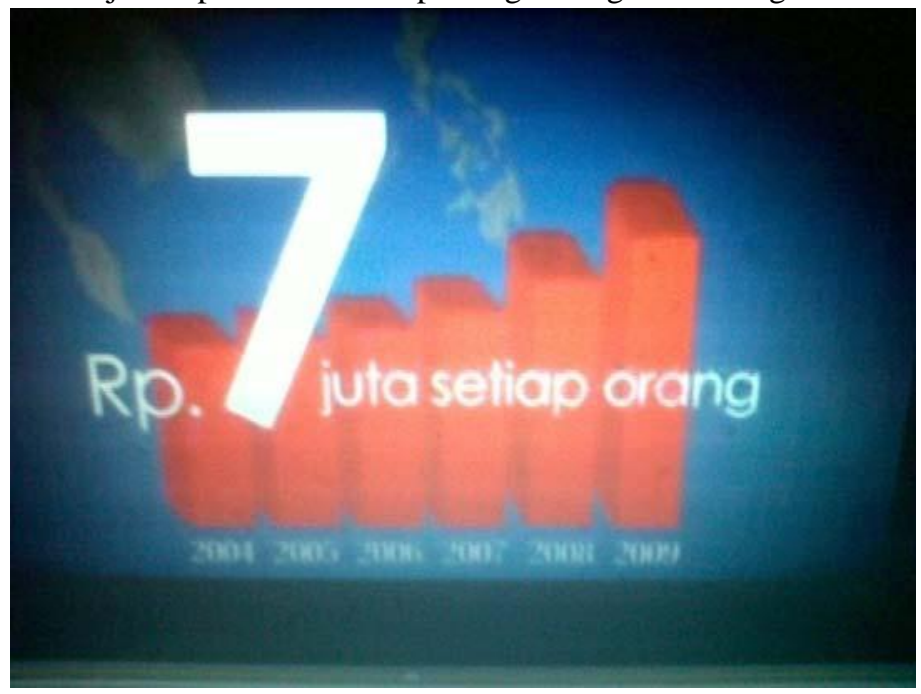

Gambar 9. Visualisasi diagram hutang Indonesia

Gambar diagram utang yang terus meningkat dari tahun-ketahun dengan warna merah. Warna merah biasa digunakan untuk tanda bahaya. Sehingga utang Indonesia juga dalam tahap yang membahayakan.

Iklan ini cukup menohok pemerintahan SBY yang saat itu masih menjabat sebagai presiden. Mega-Prabowo cukup lihai dalam menampilkan visualisasi iklan untuk menyerang lawan politiknya tersebut.

Yang menarik dalam iklan ini terdapat visualisasi gambar SBY dan muncul stempel tulisan "Bangkrut". Dilanjutkan dengan voice over "Tanggal 10 Maret lalu presiden mengatakan pemerintah bangkrut”. 


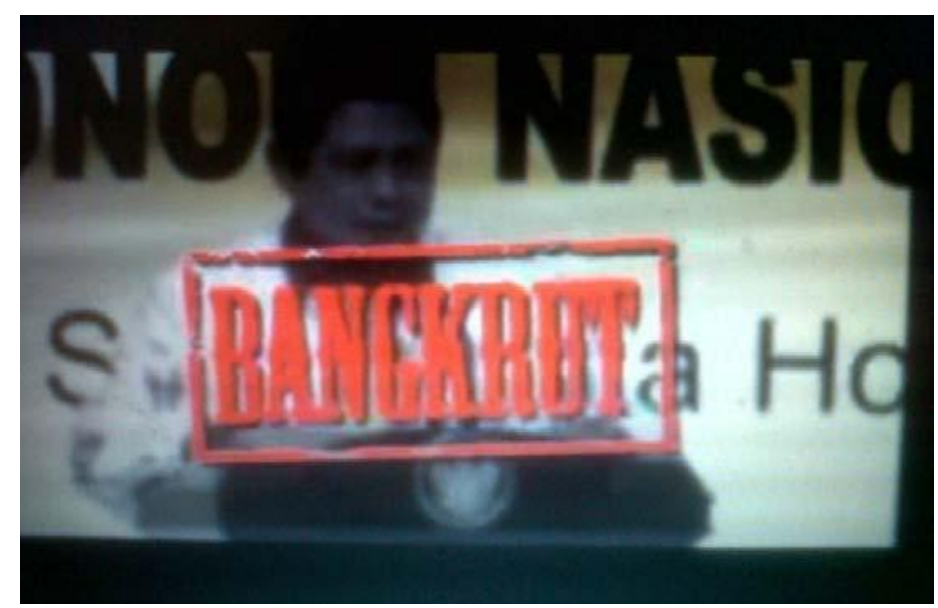

Gambar 10. Visualisasi pemerintahan SBY bangkrut.

Pasangan ini ingin memberi penjelasan pada publik, jika klaim utang negara yang menumpuk bukan sekedar klaim sepihak, namun diamini oleh SBY selaku presiden saat itu.

Dilanjutkan suara "jika pemerintah benar-benar mencintai Indonesia mari kita menjadwal utang luar negeri sejalan dengan tujuan pembangunan millennium PBB". Kalimat tersebut adalah janji yang akan dilakukan jika terpilih. Penegasannya adalah jika cinta rakyat maka harus berani menjadwal utang. Di sisi lain sangat berat bagi pemerintah untuk menjadwal hutang, karena terbentur perjanjian bilateral dan menjaga hubungan baik dengan bangsa lain. Jika menasionalisasi aset masih memungkinkan. Seperti yang dilakukan presiden Venezuela, Hugo Chaves atau presiden Bolivia, Evo Morales. Jika berhasil menjadwal hutang, pasangan ini akan menggunakan untuk membangun sesuai dengan tujuan pembangunan dari PBB.

\section{SBY-Budiono}

a) Dari rakyat untuk rakyat

Iklan ini berdurasi 60 detik, yang menceritakan tentang asal usul SBY dan Budiono. Diawali dengan voice over, "dari rakyat untuk rakyat". Diikuti dengan gambar SBY-Budiono sedang bercengkrama dengan anak-anak. Bahkan sekerumunan anakanak tersebut seolah-olah digendong di punggung SBY. 
Diterbitkan oleh Fakultas Sastra dan Budaya

Universitas Ahmad Dahlan Yogyakarta

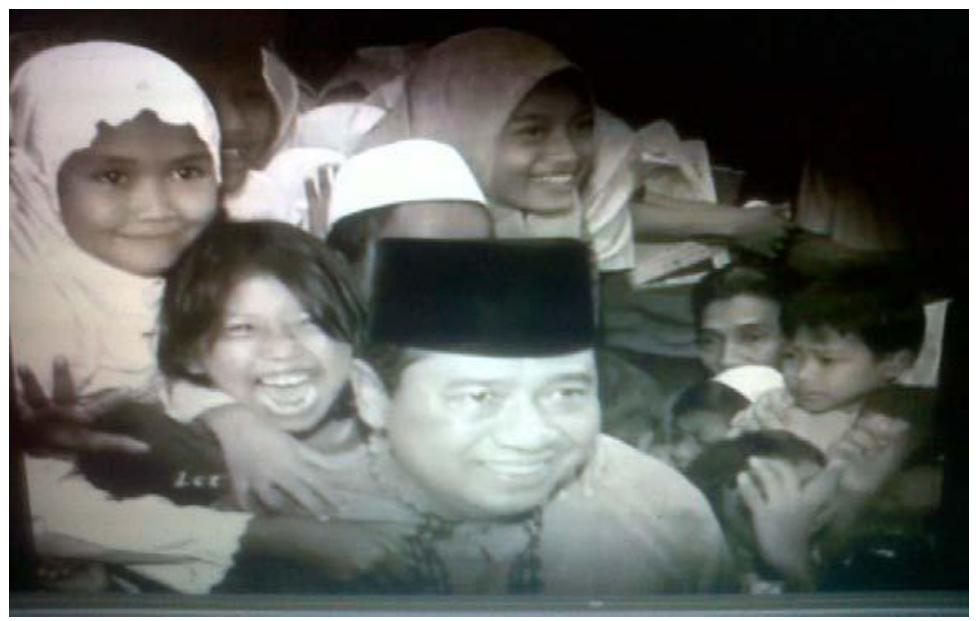

Gambar 11. Visualisasi kedekatan SBY dengan rakyat.

Pasangan SBY-Budiono dengan iklan ini ingin menunjukan bahwa dirinya berasal dari rakyat biasa. Gambar SBY bencengkrama dengan anak-anak diharapkan menjadi penegas kedekatan SBY dengan rakyat. Visualisasi dalam gambar di atas sungguh mencerminkan kedekatan dan suasana riang antara SBY dengan anak-anak. Bila dicermati gambar tersebut, terlihat SBY dengan baju "koko" atau "taqwa" sambil memakai songkok hitam. Di sini ada disparitas. Jika kesan yang ditimbulkan adalah kedekatan, maka seharusnya pakaian yang dikenakan juga harus biasa. Di sisi lain, pada kenyataannya di hari anak nasional, SBY sempat menegur anak-anak yang bicara sendiri saat berpidato. Banyak kritikan yang muncul saat itu, terkait cara SBY dalam menegur, dan ini mencerminkan cara SBY berkomunikasi dengan anak-anak kurang tepat. Tentu secara psikologis anak tersebut akan merasa terganggu. Di sini bentuk merakyatnya SBY menjadi sebuah pertanyaan.

Lalu muncul gambar masa lalu SBY, terdengar ilustrasi suara, "mereka datang dari keluarga sederhana". Bersamaan dengan munculnya gambar rumah masa kecil SBY di Pacitan. 


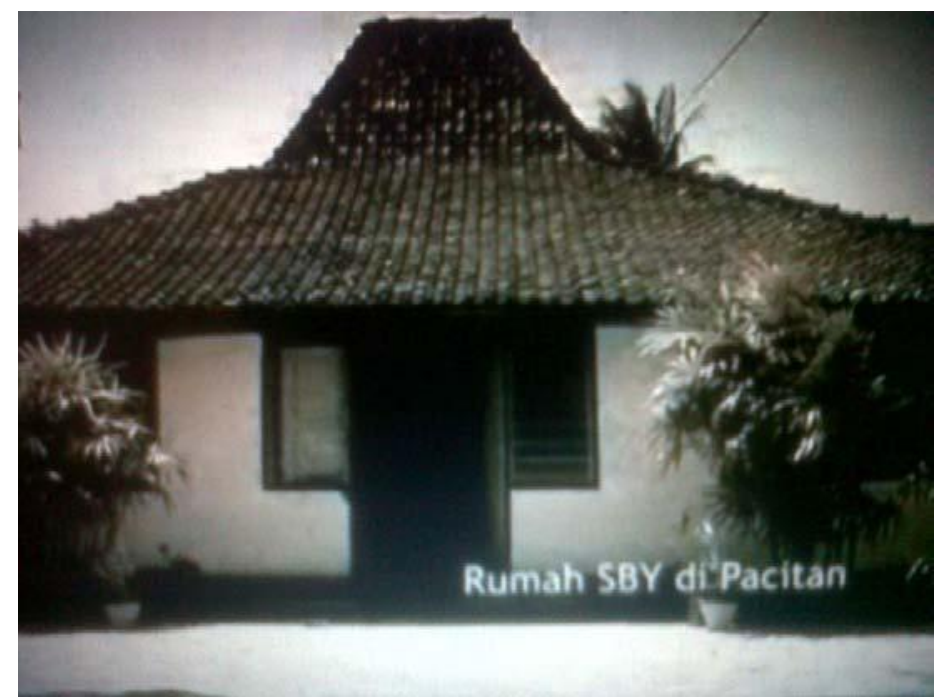

Gambar 12. Visualisasi rumah masa kecil SBY.

Kesederhanaan dari suara ilustrator dan diperkuat oleh gambar iklan, menegaskan bahwa SBY adalah rakyat biasa yang sederhana. Dimana paralel dengan mayoritas jumlah masyarakat yang masih dalam kondisi belum sejahtera, atau dengan kata lain "wong cilik". Akan tetapi, representasi pemimpin tersebut bukan hanya paralel mengenai derajat material, melainkan yang diharapkan adalah keberpihakan calon pemimpin tersebut pada rakyat kecil. Hal ini kemudian dipertegas dengan tulisan yang muncul di dalam iklan, "mereka berasal dari rakyat, mereka mengabdi untuk rakyat".

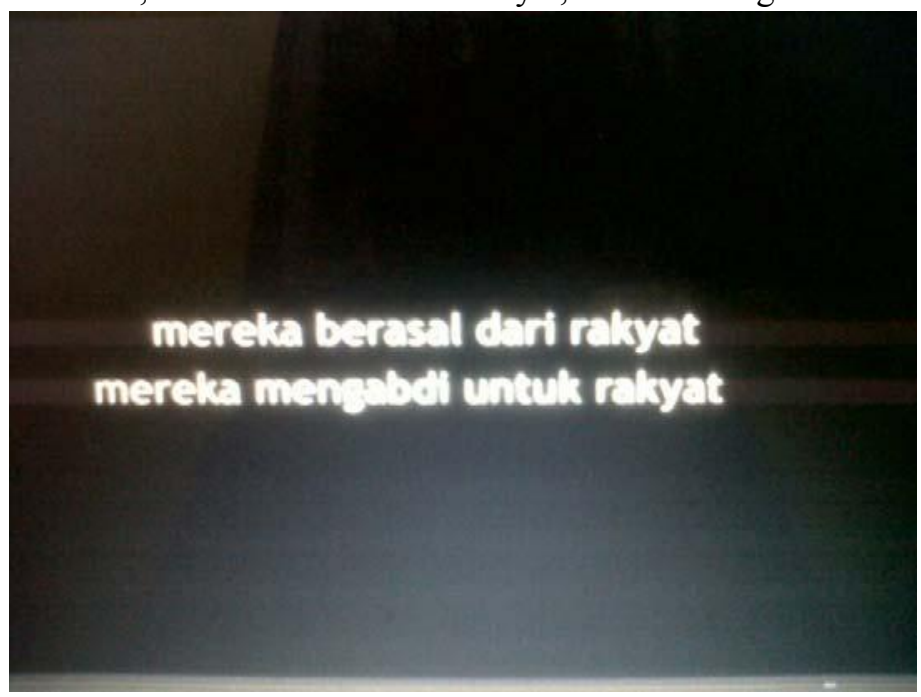

Gambar 13. Visualisasi kalimat penegas asal usul SBY-Budiono

Tulisan dalam iklan di atas diharapkan mampu meyakinkan para pemilih nantinya. Bahwa SBY dan Budiono adalah rakyat dari kalangan mereka sediri. Bukan orang lain. 
Diterbitkan oleh Fakultas Sastra dan Budaya

Universitas Ahmad Dahlan Yogyakarta

Visualisasi suara dilanjutkan "SBY sebagai prajurit dan Budiono sebagai guru". Bersamaan dengan munculnya gambar SBY saat menjadi prajurit, dengan baju doreng dan muka di cat khas prajurit dilapangan.

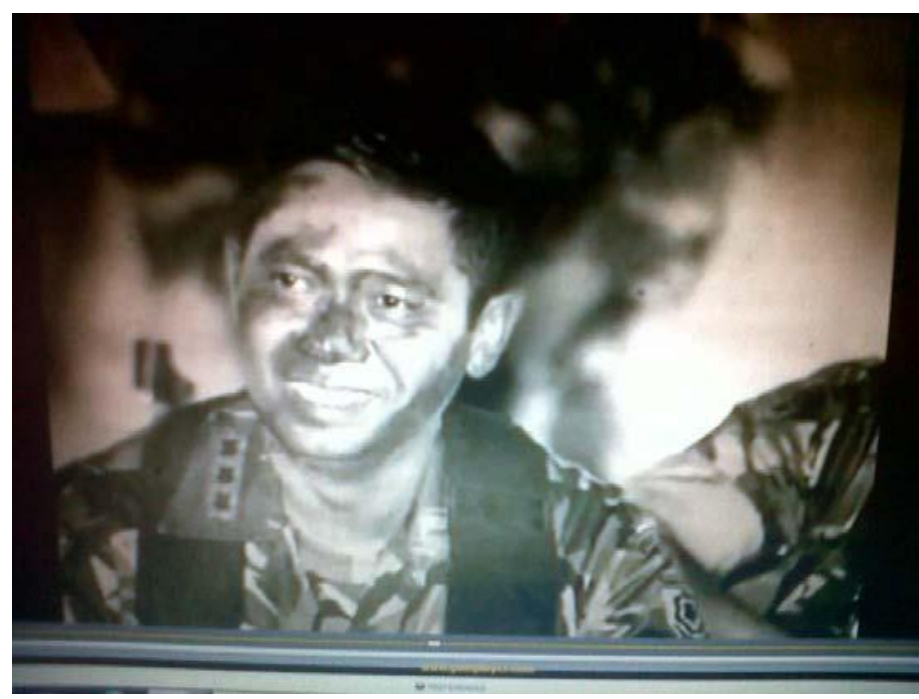

Gambar 14. Visualisasi SBY saat menjadi tentara.

Penekanan yang ingin dilakukan tim kampanye SBY adalah sosok yang tegar, kuat dan penuh perjuangan. Tentara adalah orang-orang yang terpilih untuk mengamankan negara dengan segenap pengorbanannya. Hal ini dipertegas lagi dengan voice over yang mengatakan, "Mereka mengabdi tidak memperkaya diri". Sehingga apapun yang dilakukan oleh SBY adalah semata-mata demi bangsa dan negara. Bukan untuk diri dan keluargannya. Apalagi sekedar memperkaya diri.

Voice over mengatakan, "mereka menjalankan amanat, bekerja penuh dedikasi karena mereka dekat dengan rakyat, asal usul mereka". Dari ilustrasi gambar dan voice over dipadukan untuk memberi penegasan, bahwa pasangan SBY-Budiono adalah seorang pemimpin yang amanah dan mendedikasikan semuanya untuk rakyat. Hal ini dilakukan SBY-Budiono, karena mereka berasal dari rakyat.

Dilanjutkan dengan gambar SBY-Budiono terlihat sedang berbincang-bincang. 


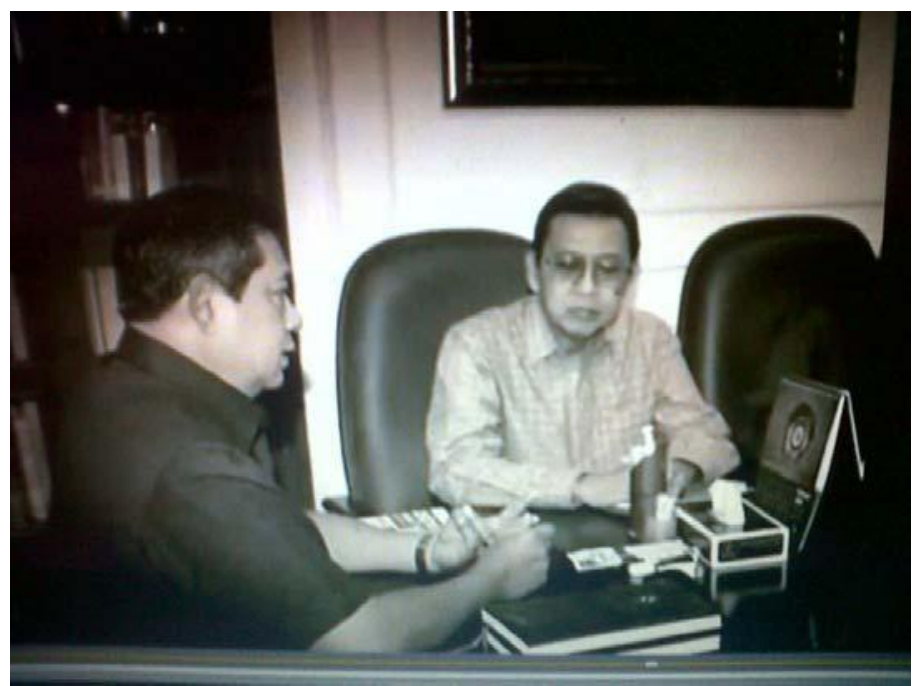

Gambar 15. Visualisasi SBY dan Budiono sedang rapat.

Gambar di atas ingin menegaskan bahwa SBY dan Budiono adalah sosok pemimpin yang kompak. Hal ini dilakukan untuk menepis anggapan selama ini, bahwa SBY kalah pengaruh dengan Jusuf Kalla. Dimana saat iklan ini muncul JK adalah wakil presiden. Publik banyak yang beranggapan bahwa pamor JK lebik menarik, sampaisampai muncul statemen " $J K$ is the real president", dari Ahmad Syafi'i Ma'arif. Keakraban yang mereka perlihatkan untuk menepis bahwa SBY sebagai presiden harus tetap memiliki peran yang dominan dibanding wakilnya kelak.

\section{b) Sabang-Merauke}

Iklan ini berdurasi 60 detik yang merupakan gubahan dari lagu iklan mie instan (indomi) dengan syair yang diganti. Diawali munculnya artis Mike Idol yang menyanyikan lagu dengan syair "dari Sabang sampai Merauke, dari Miangas sampai pulau Roote".

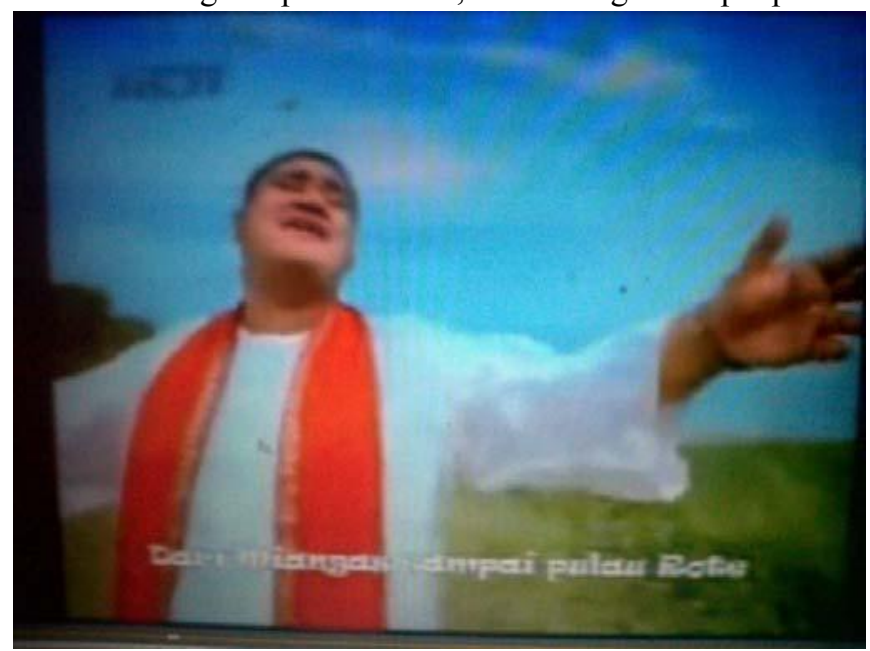

Gambar 16. Visualisasi Mike sedang menyanyi lagu SBY presidenku. 
Diterbitkan oleh Fakultas Sastra dan Budaya

Universitas Ahmad Dahlan Yogyakarta

Sabang adalah pulau diujung Sumatra dan Merauke adalah kota diujung timur wilayah Indonesia, tepatnya di provinsi Papua. Adapun pulau Rote terletak di provinsi NTT dan merupakan pulau terluar dibagian selatan wilayah Indonesia. Sedangkan Miangas adalah daerah paling ujung utara Indonesia. Kesemuannya adalah batas-batas wilayah terluar Indonesia. Tim pasangan ini ingin menegaskan bahwa daerah Indonesia sangat luas, beraneka ragam dan sudah pasti banyak masalah di dalamnya. Selain itu, bintang AFI muncul dengan pakaian merah putih, menunjukan bahwa wilayah yang disebutkan adalah wilayah dalam NKRI. Tidak bisa dipecah-pecah. Di bawah naungan nasionalisme dengan simbol merah putih.

Iklan ini ingin menyampaikan tentang keanekaragam budaya, etnis, agama. Namun agak sedikit berbeda dengan provil pribadi SBY, dimana JK yang cenderung aktif untuk menyelesaikan konflik horizontal baik itu berbau suku, agama maupun ras. JK terjun langsung untuk menyelesaikan konflik Poso, Ambon dan Aceh. Namun kurang tepat jika keberhasilan tersebut hanya dialamatkan pada JK seorang, karena presiden saat itu yaitu SBY tentu juga mempengaruhi dalam pengambilan kebijakan tersebut.

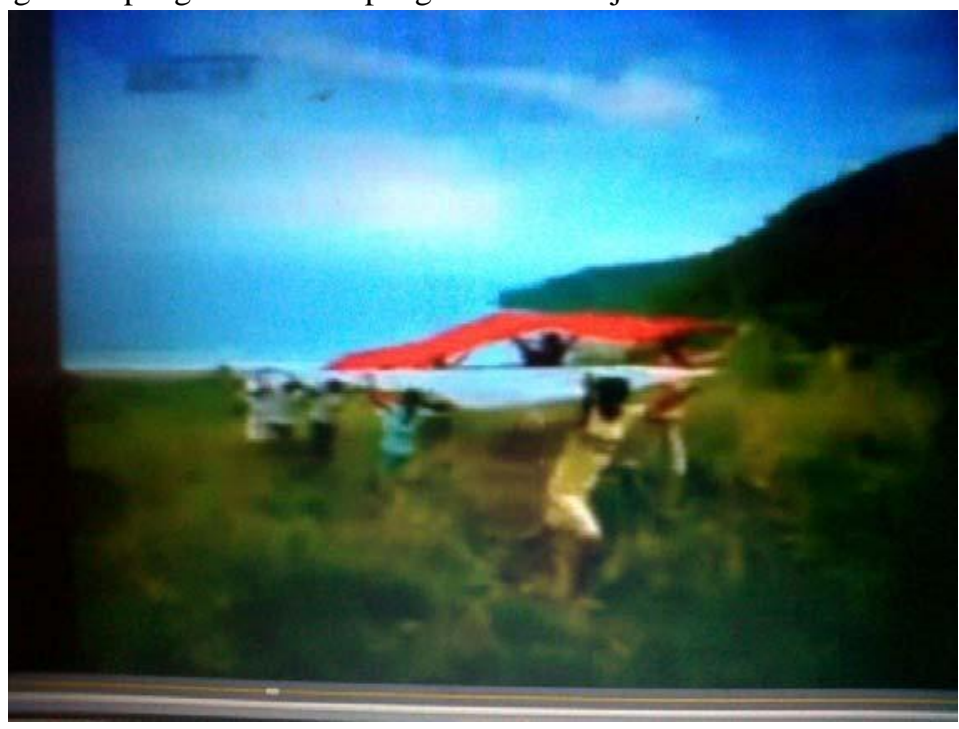

Gambar 17. Visualisasi anak bermain sebagai wujud kemakmuran.

Sekumpulan pemuda di bukit sedang berlarian sambil melanjutkan lagu "pilihan partai boleh berbeda, presiden tetap SBY". Dilanjutkan dengan gambar seorang laki-laki mengayuh sepeda, perempuan dan laki-laki bergandengan sambil menari dan sekumpulan pemuda pemudi yang menari disusul dengan tarian adat. 


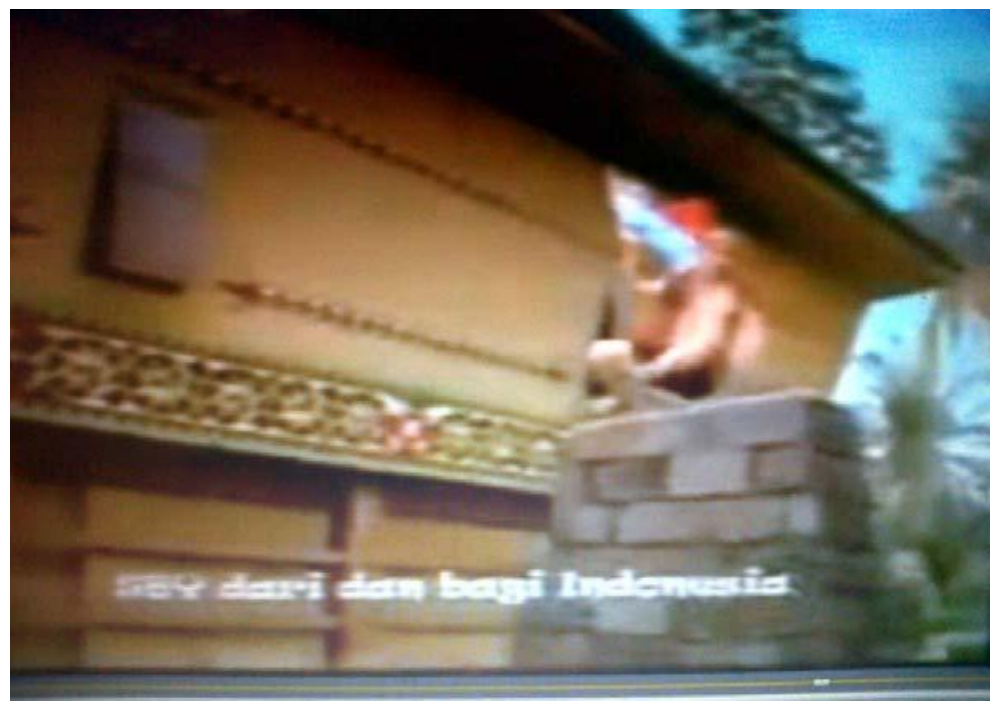

Gambar 18. Visualisasi lompat batu pulau Nias.

Iklan ini mencoba memvisualisasikan keanekaragaman budaya bangsa Indonesia di bawah naungan bendera pemersatu merah putih. Identitas yang ingin dimunculkan adalah SBY adalah sosok pemersatu bagi seluruh elemen bangsa. Tentu tidak ada yang salah dalam hal ini. Namun masih perlu bukti. Banyak kritikan yang muncul ketika masih banyak konflik yang muncul ditengah masyarakat. Sebut saja kaum agama minoritas, seperti GKI Yasmin, warga Syi'ah di Sampang, Madura, kasus penembakan orang Jawa di Aceh dan lain-lain. Lebih ironis lagi adalah perseteruan antar lembaga Negara, sebut saja kasus Cicak vs Buaya.

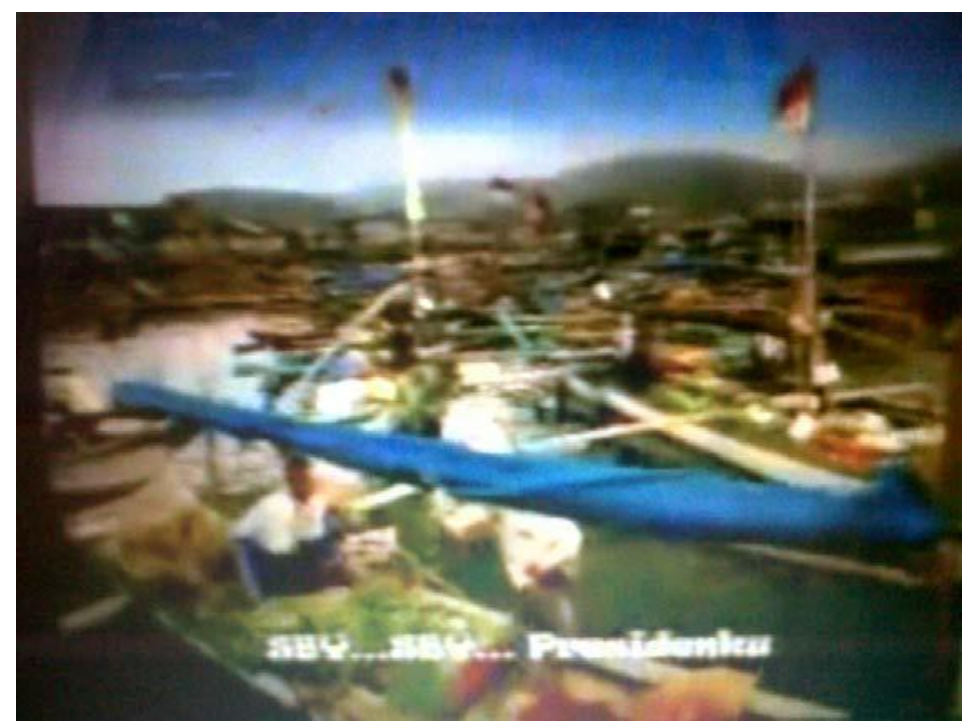

Gambar 19. Visualisasi pasar terapung sebagai wujud kemakmuran. 
Diterbitkan oleh Fakultas Sastra dan Budaya

Universitas Ahmad Dahlan Yogyakarta

Gambar suasana pasar terapung, para pedagang riang gembira bertransaksi dengan perahu mereka masing-masing. Tim pasangan ini ingin menunjukan bahwa selama pemerintahan SBY lima tahun sebelumnya telah terwujud kesejahteraan masyarakat. Adapun bendera merah putih adalah perlambang persatuan dan kesatuan. Artinya masyarakat sejahtera, bersatu dan guyup rukun selama pemerintahan SBY.

Iklan ini diakhiri dengan syair "SBY dari dan bagi Indonesia". Kalimat tersebut menjadi penegas bahwa SBY adalah sosok yang berasal dari rakyat, yang lahir dari budaya dan etnis bangsa ini. Sehingga pantas memimpin bangsa yang beraneka ragam agama, budaya dan etnis. Apalagi selama pemerintahan lima tahun yang lalu SBY sudah teruji dalam memimpin. Sehingga SBY tinggal melanjutkan agenda yang belum selesai. Hal ini relevan dengan slogan SBY, yaitu "lanjutkan".

Sebagaimana dijelaskan diatas, bahwa terdapat hubungan erat antara iklan politik dengan politik identitas. Asumsi awal, iklan terdiri dari berbagai rangkaian gambar dan juga vois over yang mengkonstruksi sebuah alur untuk menciptakan dan mengkonstruksi sosok dengan identitas tertentu. Kali ini akan dibahas secara mendalam mengenai konstruksi identitas tersebut.

\section{Politik Identitas Negarawan}

Menarik untuk dicermati adalah pakaian Megawati dan Prabowo yang dikenakan dalam iklan kebanyakan adalah pakaian safari dengan dua buah saku di dada yang mirip dengan yang biasa dikenakan oleh Soekarno. Bahkan dalam iklan Mega-Prabowo secara terang-terangan menggunakan visualisasi Soekarno dan Hatta. Begitu juga dengan pasangan JK-Wiranto yang melambaikan tangan dengan latar belakang tugu proklamasi. Tentu hal ini dimaksudkan untuk menunjukan semangat proklamasi yang dilakukan oleh Soekarno dan Hatta beberapa dekade lalu. Jika muncul kata proklamasi, maka asosiasi akan langsung tertuju pada sosok sang proklamator. Dan proklamator adalah sosok negarawan. Akan tetapi tidak semua orang yang berada di tugu proklamasi dapat diidentikan dengan sang proklamator itu sendiri. Atau lebih jelasnya setiap orang yang berada di tugu proklamasi adalah negarawan. Tentu tidak salah mengatakan bahwa ada seorang negarawan yang menggunakan pakaian tertentu, berbicara dengan gaya orasi tertentu. Namun itu tidak sepenuhnya benar. Karena ukuran negarawan seseorang tidak ditentukan oleh cara dia berpakaian, berbicara maupun bentuk fisiknya.

Menurut mantan presiden Amerika Serikat, Thomas Jeferson perbedaan politisi dan negarawan adalah, "politikus memikirkan pemilihan yang akan datang, sementara negarawan memikirkan generasi yang akan datang". Hal ini diperkuat oleh mantan presiden Amerika Serikat yang lain, John F Kennedy yang mengatakan bahwa "jangan mempertanyakan apa yang bisa diberikan oleh negaramu, tetapi apa yang bisa kau berikan untuk negaramu". (tempokini.com : 2014). Bahkan tokoh bangsa Buya Syafii Ma'arif, mantan ketua umum PP Muhammadiyah menegaskan bahwa seorang negarawan adalah orang yang menempatkan kepentingan bangsa di atas kepentingan partai maupun golongan, selain itu seorang negarawan adalah seorang pemimpin bangsa yang tidak mengalami "pecah kongsi antara perkataan dan perbuatan".

Dari beberapa pendapat di atas, sungguh penting jiwa kenegarawanan bagi pemimpin bangsa. Namun tidak ada satupun yang mensematkan bahwa kenegarawanan 
seseorang diukur dari cara berpakaian seseorang. Bisa dicermati bagaimana gaya berpakaian Mahatma Gandhi atau Ahmadinejad. Mereka berpakaian alakadarnya dan tidak ada seorangpun yang meragukan kenegarawanannya. Begitu juga dengan identitas yang disematkan pada seorang koruptor. Banyak yang mengatakan bahwa koruptor itu adalah orang yang berdasi dan memakai jaz serta pakaian yang rapi. Namun banyak dijumpai bahwa pelaku korupsi tidak hanya dilakukan oleh orang-orang berdasi.

\section{Politik Identitas Kemiskinan dan Kesejahteraan}

Iklan pemilu 2009 banyak menggunakan isu-isu tentang ekonomi, kemiskinan, pendidikan dan juga kesejahteraan. Jika diperhatikan dengan seksama, agak menonjol adalah isu yang diangkat dalam iklan mengenai kemiskinan yang ada di masyarakat. Jika muncul kata kemiskinan maka yang terbersit dalam pikiran adalah anak kecil kurus perut buncit karena busung lapar, orang tua yang lusuh dengan pandangan kosong di pinggir jalan karena tidak punya tenpat tinggal, atau pemuda bergerombol bermain gitar sampil bergadang di pinggir jalan. Itulah gambaran citra tentang kemiskinan yang telah menjadi identitas dalam masyarakat.

Jika dicermati, dalam iklan politik tahun 2009, lebih kongkritnya iklan MegaPrabowo, orang miskin itu identik dengan orang yang kesulitan membeli bahan makanan pokok dan kesulitan membeli bahan bakar minyak. Kemudian sebaliknya, kesejahteraan di visualisasikan dengan pembangunan gedung pencakar langit, sawah yang hijau, pasar yang ramai. Akan tetapi itu semua tidak bisa dijadikan sebagai sebuah ukuran.

Parameter kemiskinan yang selama ini menjadi ukuran pemerintah dan realitas di masyarakat sangat timpang. Hal ini tercermin dari perbedaan data BPS dengan masyarakat yang menerima BLT sebagai kompensasi kenaikan BBM. Bahkan soal data kemiskinan pemerintah sendiri berbedabeda, tergantung konteksnya. SBY sering mengklaim ada 30,1 juta orang yang miskin sedangkan yang menerima bantuan beras miskin (raskin) sebanyak 70 juta orang. Karenannya SBY diklaim oleh tokoh lintas agama telah melakukan kebohongan publik. Sesuai dengan tujuan pembangunan milenium PBB atau MDGs (Millennium Development Goals), PBB telah menetapkan bahwa batas kemiskinan adalah ketika penghasilan setiap orang adalah di atas 2 dolar. Atau jika dikonfersi dengan rupiah adalah 20 ribu rupiah. (Kompas.com: 2011). Dengan penghasilan sebesar itu, tentu tidak cukup untuk membeli kebutuhan hidup sehari-hari.

Dalam situasi yang lain, kesejahteraan berbanding lurus dengan tingkat pendidikan. Data masyarakat yang mengenyam pendidikan dari survei ekonomi nasional menyebutkan, APM (angka partisipasi murni), SD sebesar 92,5\%, SMP sebesar 63,5\%, dan SMA sebesar 40,6\%. Dan prosentase pendidikan lebih tinggi ditingkat perkotaan dibanding pedesaan. (Pontoh, 2008 : 139). Berasumsi dari data tersebut, pendidikan dasar di Indonesia masih jauh dari harapan. Begitupula dengan persebaran atau pemerataan. Di perkotaan lebih bagus bila dibanding dengan pedesaan. Hal ini juga berlaku bagi pulau Jawa dengan luar Jawa. Dalam iklan ketiga kandidat, tidak ada satupun yang menyinggung terkait data kependidikan. 
Diterbitkan oleh Fakultas Sastra dan Budaya

Universitas Ahmad Dahlan Yogyakarta

Di sisi lain, masyarakat memiliki ukuran tersendiri mengenai batasan kemiskinan dan kesejahteraan. Jika masyarakat memiliki kecukupan dalam sandang, pangan dan papan itulah parameter kongkrit kemiskinan. Rakyat, entah itu petani maupun nelayan yang berada di pedalaman maupun pelosok desa banyak yang memiliki kekayaan dengan sawah yang luas, kebun puluhan hektar. Namun pakaian mereka tetap sederhana bahkan juga lusuh. Pandangan kosong dan bergadang di pinggir jalan sambil bermain gitar juga tidak bisa diidentikan dengan kemiskinan. Boleh jadi mereka adalah anak orang kaya yang sedang bermasalah dalam hidup. Begitu juga orang yang berdasi maupun berpakaian ala sosialita, bisa jadi mereka para pengusaha. Namun para pengusaha banyak yang memiliki hutang, dan jumlahnyapun banyak. Bahkan jika dikonfersi dengan jumlah kekayaannya, jumlah hutangnya bisa lebih besar dari kekayaanya.

\section{Politik Identitas Multikulturalisme}

Salah satu isu yang menarik untuk dijadikan komoditas politik adalah isu mengenai multikulturalisme. SBY menggunakan isu ini dalam iklannya yang berjudul "dari Sabang sampai Merauke". Iklan tersebut menggunakan jingle iklan produk mie isntan Indomie dan berusaha mengambarkan keanekaragaman suku bangsa, agama, etnis dan budaya, bahkan juga berbagai agama tercermin dalam iklan tersebut. Mulai dari lompat batu pulau Nias, tari Bali, alat musik gamelan, tari pasaman Aceh silih berganti menghiasi.

Ada beberapa hal yang bisa kita cermati. Diantarannya adalah SBY-Budiono ingin menunjukan bahwa mereka adalah orang yang mengakui keanekaragaman sara (suku, agama, ras dan adat-istiadat) di Indonesia. Kemudian mereka bermaksud melindungi dan mengayomi berbagai perbedaan tersebut. Kenyataan ini tentu bisa dilihat dan dikaji bahkan bisa untuk diperdebatkan. Pada kenyataannya, pada massa pemerintahan SBY masih banyak kasus-kasus yang berkebalikan dengan gambaran dalam iklannya. Sebut saja kasus penyerangan jamaah Ahmadiyah Bima, pengusiran dan kerusuhan yang terjadi pada warga Siah di Sampang, kasus gereja Yasmin di Bogor serta kasus-kasus lain yang masih banyak.

Berhubung terjadi ketimpangan antara kebijakan dan janji yang telah terucap, para tokoh lintas agama melakukan konfrensi pers pada bulan Januari 2011. Para tokoh yang berkumpul di kantor PP Muhammadiyah mengkritisi pemerintahan SBY yang dianggap telah melakukan kebohongan. Salahsatu kebohongan yang diungkapkan oleh tokoh lintas agama soal kerukunan beragama. SBY dalam janjinya saat kampanye mengatakan akan menjaga kerukunan dan melindungi kaum minoritas. Tetapi faktanya, sejak tahun 2004 telah terjadi kasus penyerangan dan tindak kekerasan atas nama agama sebanyak 33 kasus dan kebanyakan kasus tersebut tidak tuntas. (politik.news.viva.co.id : 2011). Artinya, politik identitas yang coba SBY sematkan dalam dirinnya terkait jiwa multikulturalis tentu masih jauh dari realitas. Dalam iklan SBY seolah-olah digambarkan sebagai sosok yang melindungi kaum minoritas dan menjunjung tinggi toleransi dan perbedaan, tetapi fakta berkata lain.

Kasus ini bila dibandingkan dengan tokoh anti Apartheid di Afrika Selatan, Nelson Mandela serasa sangat timpang. Mungkin agak berlebihan jika membandingkan antara SBY dan Nelson Mandela, tetapi mereka adalah sama-sama sosok pemimpin bangsa yang dituntut mengambil kebijakan kenegarawanan. Dunia mengapresiasi langkah Nelson Mandela setelah 20 tahun di penjara karena menentang kebijakan politik yang 
mendeskreditkan kelompok ras kulit hitam, begitu dia keluar dari penjara mengajak semua orang kulit hitam untuk memaafkan dan menganggap semua ras adalah kelas yang sama. Dunia mengapresiasi langkah tersebut dan dunia belajar cara memaafkan dengan penuh kemulyaan.

\section{Politik Identitas Merakyat}

Keberadaan orang kecil atau tokoh politik sering menamai dengan wong cilik dalam bahasa Jawa, cukup familiar pula di agenda dan kegiatan politik. Termasuk didalam iklan. Orang kecil atau masyarakat bawah dikonotasikan sebagai masyarakat yang hidup di pinggiran desa, berpenghasilan rendah, tidak berpendidikan dan juga tidak memiliki pangkat maupun jabatan apapun. Keberadaan mereka sering dijadikan sebagai komoditas mencari simpati dan mendongkrak elektabilitas elit politik. Iklan MegaPrabowo misalnya, terlihat bagaimana Mega bercanda dengan ibu-ibu pedagang pasar, SBY terlihat bercengkrama dengan anak-anak kecil. Bahkan representasi rakyat kecil dijadikan sebagai slogan dalam kampanye. Iklan Mega yang menyatakan bahwa "MegaPrabowo, Pro kerja pro rakyat". Kemudian iklan SBY yang menyatakan "dari rakyatuntuk rakyat". Lengkap sudah rakyat menjadi materi dan komoditas iklan kampanye.

Tentu tidak ada yang salah apalagi dosa dengan itu semua. Permasalahannya adalah apakah semua tindakan dalam iklan itu tercermin dalam tindakan keseharian para kandidat atau hanya dijadikan sebagai bumbu untuk mencari popularitas dan elektabilitas saja.

Sedikit gambaran, menjelang pemilu 2009, SBY telah berencana untuk maju kembali. Strategi mendulang popularitas mulai dilancarkan. SBY pada tahun 2008 mengundang para wartawan di istana kepresidenan untuk berbuka puasa bersama. Dan dimulailah pertemuan intens terhadap wartawan setelahnya. Yang biasanya banyak kebijakan yang disampaikan oleh juru bicara presiden, mulai saat itu bahkan hal-hal kecil ditanggapi sendiri oleh SBY. Selain itu, hal-hal yang positif dan kabar-kabar baik "mendongkrak popularitas" yang SBY sampaikan di awal-awal jumpa pers. Di sisi lain, perlu diketahui bahwa sejak pertama menjabat wapres, hampir setiap setelah jum'at Jusuf Kalla mengundang wartawan untuk jumpa pers. Dengan intensitas SBY jumpa pers dengan wartawan tersebut, pemberitaan SBY di media massa mengungguli JK yang sudah sejak lama melakukan jumpa pers dengan wartawan, (Nugroho, 2010 : 142-143). Untuk dekat dengan wartawan saja perlu sebuah momentum seperti pemilu. Sangat mungkin untuk dekat dengan rakyat juga membutuhkan momentum.

Megawati, Prabowo, Budiono adalah para tokoh-tokoh bangsa yang tentu memiliki kesibukan yang luarbiasa. Prabowo sibuk mengurus bisnis dan partai. Budiono sibuk menjadi gubernur Bang Indonesia. Megawati sibuk mengurus partai. Kesempatan untuk bercengkrama, bercanda dengan anak-anak, petani, pedagang pasar tentu bukan hal yang mustahil. Namun agak langka jika itu terjadi secara intens, mengingat kesibukan mereka. Memang, sistem demokrasi presidensiil yang diterapkan di Indonesia berimplikasi pada pemilihan presiden, kepala daerah dan juga anggota legislatif menjadi dipilih langsung oleh rakyat. Akibatnya kandidat atau para politisi memerlukan interaksi langsung antara konstituen dengan para elit politik. Para politisi berlomba-lomba untuk dikenal dan meraih simpati publik. Cara yang paling instan adalah dengan membuat iklan secara besar-besaran. Dan substansi dari isi iklan merupakan formulasi terpenting. Jadilah kedekatan dengan 
Diterbitkan oleh Fakultas Sastra dan Budaya

Universitas Ahmad Dahlan Yogyakarta

rakyat dibuat sedemikian rupa, diberi bumbu, dilebih-lebihkan dan akhirnya

dipublikasikan agar persepsi publik terkonstruksi.

\section{E. Kesimpulan}

Dari pemaparan di atas, dapat ditarik kesimpulan bahwa:

1. Dari penelitian ini ditemukan identitas politik yang dimunculkan oleh masingmasing kandidat. Politik identitas ini muncul ketika iklan diuraikan dengan pendekatan sosial, budaya dan politis yang menjadi latarbelakang masingmasing kandidat. Baik secara visualisasi gambar maupun suara. Politik identitas yang muncul dalam iklan adalah negarawan, kemiskinan, kesejahteraan, multikulturalisme dan merakyat.

2. Politik identitas negarawan dilakukan oleh pasangan Mega-Prabowo. Hal ini didasarkan pada pakaian yang dikenakan Mega-Prabowo selama melakukan iklan senantiasa mirip dengan pakaian yang dikenakan oleh mantan presiden Soekarno. Yaitu baju safari dengan saku empat buah. Itu semua tentu mempunyai maksud dan tujuan. Namun yang penting sebenarnya bukan pakaian seseorang yang menentukan sukses dan tidaknya sebuah kepemimpinan, atau dengan bahasa lain pakaian tidak lantas menjadi penyebab kesejahteraan meningkat, bangsa menjadi kuat berwibawa atau negara menjadi maju.

3. Sedangkan isu kemiskinan dan kesejahteraan dilakukan oleh pasangan MegaPrabowo. Pasangan ini lebih mudah mengklaim ketidak mampuan dan ketidak berhasilan pasangan SBY selaku presiden incumbent. Dan salahsatu ketidak berhasilannya adalah masih banyaknya warga yang miskin atau belum sejahtera. Hal ini dikarenakan Mega merasa tidak bertanggungjawab selama kepemimpinan SBY.

4. Identitas multikulturalis dilakukan oleh pasangan SBY-Budiono. Yaitu dengan memunculkan berbagai tarian adat istiadat, tari Bali, gamelan Jawa dan lompat batu pulau Nias.

5. Dan isu atau identitas merakyat dilakukan oleh pasangan Mega-Prabowo, dan SBY-Budiono. Pasangan Mega-Prabowo mengilustrasikan kedekatan mereka dengan warga di pasar maupun dengan para petani di sawah. Sedangkan SBY bercengkrama dengan anak-anak. Bahkan anak-anak tersebut merangkul dan sangat akrab dengan SBY. Memang salah satu isu yang menarik dan mudah untuk meningkatkan elektabilitas selain isu kemiskinan adalah sosok yang dekat dengan rakyat. Tidak saja di Indinesia, dibanyak negara kedekatan seorang pemimpin dengan rakyatnya merupakan faktor penting dalam mendongkrak suara. Hal ini dilatarbelakangi bahwa para pemilih ingin semua permasalahannya diketahui oleh calon presiden dan wakilnya untuk dicarikan solusinya. Selain itu jika ada kedekatan maka komunikasi dengan pemimpin juga mudah dilakukan. 
Referensi

Pustaka:

Cogan, Brian dan Kelso, Tony. 2009. Encyclopedia of Politics, The Media, And Popular Culture. Greenwood Press. California.

Creswell, John, W. 2010. Research Design: Pendekatan Kualitatif, Kuantitatif dan Mixed. Edisi ketiga. Terj. Ahmad Fawaid. Yogyakarta: Pustaka Pelajar.

Darmawan, HBC. 2004. Sang Kandidat; Analisis Psikologi Politik Lima Kandidat Presiden dan Wakil Presiden RI Pemilu 2004. Jakarta : Kompas

Kaid, Lynda Lee (ed). 2004. Handbook of Political Communication Research. New Jersey: Laurence Erlbaum Associates

Lilleker, Darren G. 2006. Key Concepts in Political Communication. Sage Publications McNair, Brian. 2011. An Introduction Political Comunication, fifth edition. London: Routledge

Nimmo, Dan. 2010. Komunikasi Politik: Khalayak dan Efek. Terj. Tjun Surjaman. Cet. 5. Bandung: Remaja Rosdakarya

Nursal, Adman. 2004. Political Marketing: Strategi memenangkan Pemilu, Sebuah Pendekatan Baru Kampanye Pemilihan DPR, DPD dan Presiden. Jakarta: Gramedia.

Piliang, Yasraf Amir. 2012. Semiotikaa dan Hipersemiotikaa; Kode, Gaya dan Matinya Makna. Bandung: Matahari.

Soempeno, Femi Adi. 2008. Prabowo Bintang Tiga: Dari Cijantung Bergerak ke Istana.

Yogyakarta: Galang Press

Thoha, M. Robbani. 2009. Perempuan Yang Dikorbankan : Lahirnya Pseudo-Soekarnoisme. Klaten : Gardu Baca Indonesia.

Internet:

http://boedionomendengar.com/tentang-boediono/profil/. Diakses 10 September 2014.

http://wapresri.go.id/index/profil. Diakses 10 September 2014. http://politik.news.viva.co.id/news/read/199802-

18-kebohongan-dibacakan-di-depan-sby.

diakses 8 November 2014.

Majalah / Koran:

Koran Kompas 2 Juni 2009. 